2019-08-28

Notch Coordinates Periodontal

Ligament Maturation through Regulating

Lamin A

\title{
Denes, BJ
}

http://hdl.handle.net/10026.1/14822

\subsection{7/0022034519871448}

Journal of Dental Research

SAGE Publications

All content in PEARL is protected by copyright law. Author manuscripts are made available in accordance with publisher policies. Please cite only the published version using the details provided on the item record or document. In the absence of an open licence (e.g. Creative Commons), permissions for further reuse of content should be sought from the publisher or author. 


\section{Journal of Dental Research}

\section{Notch coordinates periodontal ligament maturation through regulating Lamin A}

\begin{tabular}{|c|c|}
\hline Journal: & Journal of Dental Research \\
\hline Manuscript ID & JDR-19-0375.R2 \\
\hline Manuscript Type: & Research Reports \\
\hline $\begin{array}{r}\text { Date Submitted by the } \\
\text { Author: }\end{array}$ & 31-Jul-2019 \\
\hline Complete List of Authors: & $\begin{array}{l}\text { Denes, Balazs; Universite de Geneve, Orthodontics } \\
\text { Bolton, Chloe; Peninsula Dental School } \\
\text { Illsley, Charlotte; Peninsula Dental School } \\
\text { Kok, Wai Ling; Peninsula Dental School } \\
\text { Walker, Jemma; Plymouth University Peninsula Schools of Medicine \& } \\
\text { Dentistry, Peninsula Dental School } \\
\text { Poetsch, Ansgar ; University of Plymouth, School of Biomedicine, Faculty } \\
\text { of Medicine and Dentistry } \\
\text { Tredwin, Christopher; Peninsula Dental School } \\
\text { Kiliaridis, Stavros; Univ. Geneve, , Dept Orthodontics } \\
\text { Hu, Bing; Peninsula Dental School, }\end{array}$ \\
\hline Keywords: & $\begin{array}{l}\text { Tooth development, Periodontal ligament (PDL), Occlusion, Molecular } \\
\text { biology, Cell biology }\end{array}$ \\
\hline Abstract: & $\begin{array}{l}\text { Tooth eruption is a continuous biological process with dynamic changes } \\
\text { at cellular and tissue levels particularly within the periodontal ligament } \\
\text { (PDL). Occlusion completion is a significant physiological landmark of } \\
\text { dentition establishment. However the importance of the involvement of } \\
\text { molecular networks engaging in occlusion establishment on the final PDL } \\
\text { maturation are still largely unknown. In this study, using rat and mouse } \\
\text { molar teeth and a human PDL cell line for RNAseq and proteomic } \\
\text { analysis, we systematically screened the key molecular links in } \\
\text { regulating PDL maturation before and after occlusion establishment. We } \\
\text { discovered Notch, a key molecular pathway in regulating stem cell fate } \\
\text { and differentiation, is a major player in the event. Intercepting Notch } \\
\text { pathway by deleting its key canonical transcriptional factor: RBP-Jkappa } \\
\text { using conditional knock out strategy in the mice delayed PDL maturation } \\
\text { We also identified that Lamin A, a cell nuclear lamina member, is one } \\
\text { unique marker of PDL maturation and its expression is under the control } \\
\text { of Notch signalling. Our study therefore provides a deep insight of how } \\
\text { PDL maturation is regulated at molecular level and we expect the } \\
\text { outcomes to be applied for a better understanding of the molecular } \\
\text { regulation networks in physiological conditions such as tooth eruption } \\
\text { and movement, and also for periodontal diseases. }\end{array}$ \\
\hline
\end{tabular}




\section{SCHOLARONE" Manuscripts}




\section{Date submitted: 4/19/2019 \\ Date last revised: 7/31/2019 \\ Date accepted: 8/2/2019}

\section{Notch coordinates periodontal ligament maturation through regulating Lamin A}

Balazs Jozsef Denes ${ }^{1}$, Chloe Bolton², Charlotte Sara Illsley², Wai Ling Kok ${ }^{2}$, Jemma Victoria Walker ${ }^{2}$, Ansgar Poetsch ${ }^{3}$, Christopher Tredwin ${ }^{2}$, Stavros Kiliaridis ${ }^{1}$, Bing $\mathrm{Hu}^{2 *}$

1. Department of Orthodontics, University Clinic of Dental Medicine, University of Geneva, Genève 4 CH, Rue Michel-Servet 1, 1211, Switzerland

2. Stem Cells \& Regenerative Medicine Laboratory, Peninsula Dental School, Faculty of Medicine and Dentistry, University of Plymouth, 16 Research Way, Plymouth, PL6 8BU, United Kingdom

3. School of Biomedicine, Faculty of Medicine and Dentistry, University of Plymouth, 16 Research Way, Plymouth, PL6 8BU, United Kingdom

*Corresponding author

Prof. Bing Hu: bing.hu@plymouth.ac.uk

Running title: Notch controls periodontal ligament development

Key words: Tooth; Periodontal ligament; Occlusion; Notch, Lamin A 


\begin{abstract}
Tooth eruption is a continuous biological process with dynamic changes at cellular and tissue levels particularly within the periodontal ligament (PDL). Occlusion completion is a significant physiological landmark of dentition establishment. However the importance of the involvement of molecular networks engaging in occlusion establishment on the final PDL maturation are still largely unknown. In this study, using rat and mouse molar teeth and a human PDL cell line for RNAseq and proteomic analysis, we systematically screened the key molecular links in regulating PDL maturation before and after occlusion establishment. We discovered Notch, a key molecular pathway in regulating stem cell fate and differentiation, is a major player in the event. Intercepting Notch pathway by deleting its key canonical transcriptional factor: RBP-Jkappa using conditional knock out strategy in the mice delayed PDL maturation. We also identified that Lamin A, a cell nuclear lamina member, is one unique marker of PDL maturation and its expression is under the control of Notch signalling. Our study therefore provides a deep insight of how PDL maturation is regulated at molecular level and we expect the outcomes to be applied for a better understanding of the molecular regulation networks in physiological conditions such as tooth eruption and movement, and also for periodontal diseases.
\end{abstract}




\section{Introduction}

Tooth eruption is accompanied by the development and maturation of PDL (Cho and Garant 2000). Recent studies suggest PDL originates from dental follicle progenitors that can be either Osx Cre (Ono et al. 2016) and/or PTHrP-Cre positive (Takahashi et al. 2019). During preocclusal eruption phase, a tooth performs axial movement till occlusion is reached, as such no exogenous tension or compression forces are applied on PDL yet. In parallel to the tooth eruption, mesenchymal cells inside PDL secrete increasing amounts of extracellular matrix such as collagen and elastin, which further polymerise into collagen fibres and elastic fibres (Berkovitz and Moxham 1990). Upon contacting the opposite tooth, i.e. the occlusion is established and root development is completed. The PDL fibres are then organized into thick bundles and suspend the tooth in the alveolar socket, hence are under the challenge of constant stretching force, facilitating the tooth to adapt to the biting force and prevent tissue damages (Beertsen et al. 1997).

The molecular networks and mechanisms linking occlusion establishement with PDL development has not been previously systemically screened yet. In many systems, Notch signalling plays a key role in controlling stem cell maintenance and differentiation (Cheung and Rando 2013). Notch proteins are transmembrane receptors that act through cell-to-cell and cell-to-matrix signalling (Giaimo and Borggrefe 2018). Binding of Notch receptor to ligand leads to the cleavage of the receptor's intramembrane sites and releasing of the intracellular domain (ICD), which translocates into nucleus and binds to the RBP-Jkappa transcription effector complex. Notch receptors are also sensitive to extracellular forces, and a small amount of force can reveal the S2 cleavage site for proteinases, which leads to release of the ICD domain and gene transcription (Kopan and Ilagan 2009). In the tooth, increasing evidence suggests that Notch is essential in the pulp and cervical loop stem cell maintenance and terminal odontoblast differentiation, as well as in tooth pulp wound healing ((Kurpinski et al. 2010; 
Lovschall et al. 2007), and Walker et al., in press). However, although Notch pathway has been implicated in inducing osteogenic differentiation of cultured PDL cells (Li et al. 2014; Nakao et al. 2009; Osathanon et al. 2013), its function in periodontal ligament development and particularly maturation has not been elucidated.

In this study, we provide novel in vivo and in vitro evidence highlighting the important role of Notch pathway in periodontal ligament development and maturation with nuclear lamina protein Lamin $A$ as a direct target.

\section{Materials \& Methods}

\section{Animals}

The Wistar rat and tooth eruption stages were determined based on data of a previous study (Denes et al. 2018) and verified by micro-CT scans. The work was approvied by the ethics committee of animal research of the Canton of Geneva ( $\left.{ }^{\circ} \mathrm{GE} / 72 / 15\right) . R B P-J_{\kappa a p p a}$ loxp/loxp and Coll $\alpha 2$-Cre mice are as reported previously (Hu et al. 2010).

\section{Laser capture microdissection}

Mandibles were dissected and immediately frozen in PrestoChill (Milestone, Type 51420) at $40^{\circ} \mathrm{C}$ and stored at $-80^{\circ} \mathrm{C}$. Sections were performed with a cryostat and transferred to PETmembrane slides with the CryoJane Tape system (Leica Biosystems). Slides were dehydrated successively with $70 \%, 95 \%, 100 \% \mathrm{EtOH}$ at $-20^{\circ} \mathrm{C}$. Microdissection of the periodontal ligament (PDL) was performed at the cervical 1/3 PDL region. For each developmental stage, 4 individual animals were used.

\section{RNAseq statistical analysis}

RNA extraction was performed according to RNeasy Micro Kit (Qiagen $\left.{ }^{\circledR}\right)$. RNA quantity and quality was evaluated with Agilent 2100 Bioanalyzer (Agilent Technologies). RIN number 
equal or greater to 7 was required for the sample for analysis. Total RNA was amplified and Next-Generation Sequencing with the Illumina HiSeq 4000 was performed with protocol Smarter + Nextera and the reference genome Rattus Norvegicus. Quality was assessed by FastQC v.0.11.5 and resulted in values between 32 and 40 (error: 1/1'000 to 1/10'000). The reads (length $=100 \mathrm{bp}$ ) were mapped with the STAR v2.5.3a software to the reference genome and showed good alignment percentage $(71.7 \% \pm 5.9)$. Biological quality control and summarization were done with the PicardTools v2.9.0 with percentage of mRNA bases as average $63 \%$. The normalization and differential expression analysis was performed with the R/Bioconductor package edgeR v.3.16.5 and statistical significance was assessed with General Linear Model, negative binomial distribution and a quasi-likelihood F-test. Threshold for significance was set at $\mathrm{p}$-value $<5 \%$ and fold change $(\mathrm{FC})>1.5$. The RNAseq data can accessed through number: GSE129458 from https://www.ncbi.nlm.nih.gov/geo/. Enrichment analysis of RNAseq was performed with GO Ontology database and analyzed with PANTHER Overrepresentation Test. Fischer test was used with false discovery rate (FDR) correction applied. Biological processes, molecular functions and cell compartment analyses were classified based number of genes.

\section{Rat paraffin sections}

The cryoembedded mandibles were washed in distilled water to remove MCC, fixed in 4\% paraformaldehyde (Merck), decalcified in Osteosoft (Sigma-Aldrich) or 14\% EDTA (pH7.4) for a period of 6-weeks, embedded in paraffin. The paraffin blocks were cut into sections of $3 \mu \mathrm{m}$ thickness at the second root-pair of the first molar for rat samples and $10 \mu \mathrm{m}$ for mouse teeth.

\section{Immunohistochemistry/Immunofluorescence}


4-5 individual animals were used for each genotype at each defined stage. Osteosoft (SigmaAldrich) or $14 \%$ EDTA (pH7.4) decalcified samples were cut into $3 \mu \mathrm{m}$ thickness sections. The sections were deparafinized and antigen retrieval was done in citrate buffer $(\mathrm{pH} 8.0)$ at $98^{\circ} \mathrm{C}$ for 20 min or a microwave at 750w for 1 minute, followed by blocking in PBS containing 5\% donkey serum, $0.25 \%$ cold water fish gelatine and $0.25 \%$ bovine serum albumin for $1 \mathrm{~h}$ at room temperature and incubated with rimary antibodies for overnight at $4^{\circ} \mathrm{C}$, and secondary antibodies for $2 \mathrm{~h}$ at room temperature. and counterstained with 4'-6-diamidino-2-phenylindole (DAPI). Imaging was performed with a Leica DMI6000 confocal microscope. For immunohistochemistry, Vectastain with DAB substrate were used. For details please see Appendix Table 3. Goldner staining was used for collagen staining.

\section{Cell cultures and treatment}

Human periodontal ligament fibroblasts (hPLF, ScienCell, Catalog \#2630) were cultured in DMEM/F-12 with 20\% FBS and 1\% Antibiotic-Antimycotic. For Jagged1 treatment, after overnight seeding and cell confluency reached to $70 \%$, Jagged 1 was added to the medium to reach to a final concentration of $100 \mathrm{ng} / \mathrm{ml}$. Cultures were fixed after $24 \mathrm{~h}$ of Jag1 treatment with 4\% PFA at room temperature for 20 minutes and then washed $2 \mathrm{x}$ with PBS (10mM).

Stretching experiments were performed with the stretching device and silicone membranes (Strex USA, ST-140-04) (Appendix Figure 1 and 2). The membranes were coated with rat tail collagen type I (Life Technologies, A1048301) and $\mathrm{HCl}$ at 1:1 ratio overnight at $37^{\circ} \mathrm{C}$. Cells were seeded as $2 \times 10^{5}$ cells per membrane. Cells were stretched for $6 \mathrm{~h}, 12 \mathrm{~h}$ and $24 \mathrm{~h}$ at $37^{\circ} \mathrm{C}$ alongside controls. 


\section{Quantitative real-time RT-PCR}

Tirpilated samples were used for each gene analysis. Total RNAs was extracted using the penol-chloroform technique and reverse transcription of was achieved with High-Capacity cDNA synthesis kit (Thermo Fisher Scientific), as previously described (Singer et al. 2019). The PCR reaction was performed with SYBR Green I Master Mix (Roche) on a LightCycler 480 II Real-Time PCR system (Roche Molecular Diagnostics) for 45 cycles. 36 beta4 gene was used as housekeeping gene to normalize samples with the $2^{-\Delta \Delta \mathrm{Ct}}$ method. All analyses were performed with three replicates as described previously (Hu et al. 2012). For the primers used in this study please see Appendix Table 3.

\section{Nanoscale Liquid Chromatographic-Electrospray Ionization-Tandem Mass Spectrometry (nLC-ESI-MS/MS)}

Duplicted samples were used for the analysis. In-gel tryptic digestion of proteins was carried out as described in (Costa et al. 2018). Peptides were separated on an HSS T3 column (waters) and injected into an Orbitrap Elite MS using a 90 min gradient from 2 to $30 \%$ acetonitrile, $0.1 \%$ formic acid. Full MS scans in the orbitrap and fragmentation of 20 most intense precursors in parallel was done. Protein identification and label-free quantification was done with MaxQuant (Cox et al. 2014) and further statistical analysis with Perseus (Tyanova et al. 2016). Differential expression of fold change $>2$ was analyzed with Gene Ontology (GO) enrichment of biological processes powered by Panther Database (pantherdb.org) and clustering was performed with String Database v11.0 (string-db.org). For in vivo proteomic analysis, electrospray ionization Liquid-Chromatography-Mass Spectrometry/Mass Spectrometry (ESI-LC-MSMS) was performed on rat mandible periodontal ligament, dissected with laser capture microdissection 
technique. The results can be access with number: PXD013379 from https://www.ebi.ac.uk/pride/archive/.

\section{Western Blotting}

Cells were washed with HBSS, collected at $10,000 \mathrm{rpm}$ for 10 minutes at $4^{\circ} \mathrm{C}$. The pellet was re-suspended in ice-cold radioimmunoprecipitation assay buffer (89901, Pierce) with protease $\&$ phosphatase inhibitor cocktail (78442, Pierce) and incubated on ice for 30 minutes then spun down at $10,000 \mathrm{rpm}$ for 10 minutes at $4^{\circ} \mathrm{C}$. The supernatant was collected and quantified with BCA method (23225, Pierce). Protein were separated with 4-12\% NuPAGE Novex Bis-Tris gel and transferred to polyvinylidene membrane, detected with iBind Flex Western device (SLF2000S, Invitrogen). Antibodies were diluted in iBindFlex solution (SLF2020, Invitrogen). Membranes were scanned with C-DiGit scanner (Li-COR, 3600-00). For antibodies see Appendix Table 3.

\section{Results}

\section{PDL has distinct gene expression profile changes upon occlusion establishment}

We selected postnatal day 18 (P18, pre-occlusion eruption) and 28 (P28, 1 week after occlusion establishment) of the Wistar rat's second root pair of the first lower molar as the studying models. The eruption stage was confirmed by daily in vivo micro-CT imaging based on our previous study (Denes et al. 2018). Histological analysis and micro-CT confirmed that the root development of P18 tooth was at the initial elongation stage, while at P28 the root development reached near completion (Figure 1A and Appendix Figure 1A). Trichrome staining showed P28 PDL was aboundant with collagen fibres, comparing to P18 (Figure 1B). As well, P28 PDL expressed significiantly higher level of Periostin (Figure 1C). To explore the transcriptome changes of PDL, we next performed RNAseq analysis on the PDL at indicated 
stages (RNAseq accession number: GSE129458). Among a total of 12,742 detected genes, we identified 1,090 genes were upregulated and 1,035 were downregulated with more than 1.5 fold changes with $\mathrm{p}$ value $<5 \%$, at P28 comparing to P18 (Appendix Table 1). Gene enrichment analysis suggested P28 has significantly increased cellular process and protein binding events comparing to P18 (Figure 1D). Heatmap of genes identified by Metacore pathway map analysis shows consistent expression throughout samples (Figure 1E). Using GO analysis to examine the biological processes and Metacore process networks, as expected, we have identified that "biomineral tissue development" and "muscle contraction" are among the most significantly changed biological processes (Figure 1F and Appendix Figure 1B).

\section{Notch signalling is dynamically changed before and after occlusion is established}

String analysis suggested Notch pathway acted as a center of the molecular networks (Figure 2A). Metacore pathway map analysis further confirmed $P I 3 K$ and Notch signalings are the top two pathways affected (Figure 2B). As the function of Notch signaling has not been decribed previously in PDL in vivo, particularly in the occlusion establishing stage, we therefore continued focusing on that pathway for our study.

In the RNAseq analysis, Notch1, Notch4 and Dll1 are the Notch pathway members that were significantly upregulated in the P28 PDL comparing to P18 $(\mathrm{p}<0.05)$, and Jagged 1 was upregulated with a marginal $\mathrm{p}$ value $(\mathrm{p}=0.067)$, and Furin was significantly downregulated $(p<0.05)$ (Figure 2C). We next compared Notch protein expression with immunofluorescence analysis. Consistent with the RNAseq results, we found that both total Notch1 and its ICD were increasingly expressed in the P28 PDL (Figure 2D and E) as well as Notch ligands such as D111 (Figure 2F), in parallel to the increased PDL maturation marker: Osteopontin (Figure 2G) (Rios et al. 2008). Interestingly, when we evaluated in parallel the other Notch receptor, Notch2 ICD's expression was at its highest level at pre-occlusal eruption stage and decreased thereafter 
(Figure $2 \mathrm{H}$ ), suggesting that Notch1 and Notch2 receptors play significant however different roles in PDL development.

\section{Intercepting Notch pathway delays PDL development and tooth eruption}

To confirm the function of Notch pathway in PDL development during occlusion establishment, we adopted the mesenchymal conditional RBP-Jkappa knockout transgenic mouse model, where the Cre recombinase expression is under the control of Collagen $1 \alpha 2$ promoter (Hu et al. 2010). Staining with specific antibodies, we observed abundant Cre protein expression in the PDL cells confirmed the deletion of the RBP-Jkappa gene in PDL cells, as well as osteoblasts at the bone surface (Figure 3A). By crossing the Collagen 1 a2 Cre transgenics with RBP-Jkappa $a^{\text {floxflox }}$ mice (Hu et al. 2012; Hu et al. 2010), phenotypically at P21 when the tooth eruption is complete in the WT mice, the mice with RBP-Jkappa deletion in PDL cells encountered significant delay of tooth eruption and root development (Figure 3B). Macroscopy analysis revealed the RBP-Jkappa knockout mice had smaller mandibles (Figure 3C) and molar crown size. (Figure 3D). Stereomicroscopy and microCT analysis and quantification (Figure 3G) suggested that while initially the root development is delayed in the RBP-Jkappa knockout mice (Figure 3E and G), the tooth crown eruption in the mutants could still be eventually completed (Figure 3F) and root length had no difference comparing the control with the knockout mice (Figure 3G). Consistantly, immunofluorescence analysis on Periostin expression suggested at P4 there were no expression of the marker (Appendix Figure 2A), while at P10 and P14 the knockout mice has a significantly delayed expression (Figure H\&I). However, after two months there are no notable difference between the control and knockout animals' PDL (Figure 2J).

In vitro stretching mirrored occlusion establishment effects on PDL cells 
To confirm if the key molecular changes identified in the in vivo RNAseq analysis were due to the stretching of PDL mesenchymal cells and its relevance to human, we next cultured human PDL cells and mimicked occlusive stretching force by inducing reciprocal force on the cells on an automatic cell stretching system (Appendix Figure 2B and C). Real-Time RT-PCR results confirmed significant induction of the mRNA expression of Notch pathway members such as Jagged 1, Dll1 and Heyl (Figure 4A), as well a panel PDL cell differentiation markers including Osteopontin (Figure 4B). To further gain insight of the molecular targets of the PDL in responding to stretching force, we performed proteomic analysis on the stretched PDL cells and found extracellular matrix protein such as collagen and periostin and the RhoA-CDC42 associated cytoskeleton regulating system were significantly changed (Figure $4 \mathrm{C}$ and D, and Appendix Table 2).

\section{Lamin A is a direct effector in PDL in responding to stretching and act as Notch down-} stream target

By comparing the in vitro PDL cell stretching results with proteomic analysis from the in vivo PDL maturation (PRIDE number: PXD013379) and RNAseq analysis, we noticed the nuclear membrane protein: Lamin A was the only molecule displaying the same upregulation pattern across the three analyses (Figure 5A). Immunofluorescent analysis confirmed that Lamin A/C expression did increase in the P28 rat PDL, comparing with P18 samples (Figure 5B). Western Blot analysis suggested Lamin A protein level is specifically induced in the stretched human PDL cells but not Lamin C (Figure 5C). Similarly, treating PDL cells with Notch ligand: Jagged 1 could induce Lamin A expression (Figure 5D). Finally, in the RBP-Jkappa knockout mice PDL, Lamin A/C expression was concomitantly reduced both at P10 and 2 months (Figure 5E and F). Therefore, Lamin $A$ is indeed an indicator of PDL maturation that is under Notch signalling control and is positively regulated by stretching force. 


\section{Discussion}

The development of PDL, alveolar bone and cementum are closely linked events. So far, particularly for PDL and alveolar bone, it is still a dearth for finding genetic tools to dissect the specific populations inside the tissues, particularly for fibroblasts and osteoblasts. However, increasing evidence have already shown that multiple signalling pathways are closely involved in the periodontium development, such as NFI-C null mice abolish root development (SteelePerkins et al. 2003) and conditional deletion of Smad4 in tooth epithelium can impede root growth (Li et al. 2015), while conditional deletion PPR using PTHrP-Cre impede tooth eruption (Takahashi et al. 2019). Notch signalling is one of the key pathways in determining mesenchymal stem cell fate and cell differentiation such as in the muscles (Conboy et al. 2003; Conboy and Rando 2002). In bone and bone marrow mesenchymal progenitors, Notch's function has been extensively descbed in protecting mesenchymal progenitors (Hilton et al. 2008). While in the tooth, previous reports and our findings suggest that Notch is important both for maintaining stem cells and differentiation but the functions are carried out via different Notch receptors: i.e. Notchl acts through maintaining stem cell pool and inducing cell differetnation and Notch2 is rather responsible for maintaining transit amplying cells ((Mitsiadis et al. 2017; Zhang et al. 2008) and Walker et al. in press). In PDL, our results confirm that Notch1 is linked with PDL final development and completion, while interestingly Notch2 preferentially functions during the pre-occlusion stage. This might reflect a different role of Notch2 in enhancing cell populating into the tissue, similar to the findings in the incisor mesenchymal stem cells (Walker et al. in press). Although we have not been able to achieve the mesenchymal specific conditional Notch receptor deletion models due to early death in embryonic stages (data not shown), it would be still interesting to apply inducible conditional deletion models to distinguish the different roles of Notch receptors in PDL development. As 
well, future studying Notch's roles such as in PDL stem cell fate control, as well as aging are highly desired (Appendix Figure 3).

In addition, our results showed that blocking canonical Notch pathway by deleting RBP-Jkappa in the PDL delayed but did not inhibit tooth eruption and PDL maturation completely, suggesting that canonical Notch is dispensable in these events. Significantly, the Notch ligands: Dll1, Dll4 and Jagged 1 expression are all highly elevated in the PDL cells upon stretching, suggesting the PDL cells play a central role in the tissue homeostasis, possibly through Notch pathway ligands production, to affect surrounding microenvironment, such as vascularisation through endothelial cell specific Notch4 receptor. One evidence to support this theory is that during orthodontic tooth movement, blood vessel proliferation and remodelling is among the early key events in the PDL (Rygh et al. 1986; Vandevska-Radunovic et al. 1994).

Lamin A is an important nuclear envelope molecule for protecting cells from DNA damage and pre-aging and its mutation can cause laminopathies including Progeria (Broers et al. 2006; Eriksson et al. 2003; Worman 2012). Lamin A gene encodes two isoforms: Lamin A and $\mathrm{C}$ that are created from alternative splicing that encode important protein for nuclear envelopes. While Lamin C is shorter and produced directly, Lamin A, which is two exons longer at C-terminal, is required to pass prelamin A stage followed by a series of posttranslational modifications initiated from the farneslation of $\mathrm{C}$ terminal cysteine (Lin and Worman 1993). We observed Lamin A transcription and translation were both elevated upon occlusion establishment, as well as under stretching condition in the PDL cells, which indicates its potential significant role in protecting the cells from stretching force induced cellular damages. The evidence that Notch signal activation by Jagged 1 treatment could also elevate Lamin A but not Lamin C expression further confirmed that Lamin A potentially has significant role in PDL development and homeostasis, which requires additional investigations. 
We hope our study is opening a new gateway and molecular clues for understanding how the PDL, one of the most dynamically changed tissues in the body, is maintained for homeostasis and integrity, not only in physiological conditions, but also for periodontal diseases.

\section{Acknowledgement}

We would like to thank the helps provided by platforms of the University of Geneva, including the iGE3 Genomics Platform, the Bioimaging Core Facility, the Histology Core Facility. This study was supported by the Swiss National Science Foundation grant $n^{\circ}$ FNRS 31003A_176131/1 to S. K., the European Union Marie Skłodowska-Curie Actions (618930, OralStem FP7-PEOPLE-2013-CIG), the European Regional Development Fund and the Biotechnology and Biological Sciences Research Council of the UK (BB/L02392X/1) to B.H. B.D., S.K. and B.H. contributed to conception and design of the work. B.D. and B.H. drafted the manuscript. B.D., C.B., C.I., W.K., J.W., A.P. and B.H. contributed to the acquisition and analysis of the data. C.T. and S.K. contributed to the interpretation of the data. All the authors critically revised the manuscript. The authors declare that there is no conflict of interest regarding the publication of this article.

\section{Material and data availability statement}

The materials used and datasets generated during and/or analysed during the current study are available from the corresponding author on reasonable request.

\section{Reference}

Beertsen W, McCulloch CA, Sodek J. 1997. The periodontal ligament: A unique, multifunctional connective tissue. Periodontol 2000. 13:20-40. 
Berkovitz BK, Moxham BJ. 1990. The development of the periodontal ligament with special reference to collagen fibre ontogeny. J Biol Buccale. 18(3):227-236.

Broers JL, Ramaekers FC, Bonne G, Yaou RB, Hutchison CJ. 2006. Nuclear lamins: Laminopathies and their role in premature ageing. Physiol Rev. 86(3):967-1008.

Cheung TH, Rando TA. 2013. Molecular regulation of stem cell quiescence. Nat Rev Mol Cell Biol. 14(6):329-340.

Cho MI, Garant PR. 2000. Development and general structure of the periodontium. Periodontol 2000. 24:9-27.

Conboy IM, Conboy MJ, Smythe GM, Rando TA. 2003. Notch-mediated restoration of regenerative potential to aged muscle. Science. 302(5650):1575-1577.

Conboy IM, Rando TA. 2002. The regulation of notch signaling controls satellite cell activation and cell fate determination in postnatal myogenesis. Dev Cell. 3(3):397-409.

Costa MI, Cerletti M, Paggi RA, Trotschel C, De Castro RE, Poetsch A, Gimenez MI. 2018. Haloferax volcanii proteome response to deletion of a rhomboid protease gene. $\mathrm{J}$ Proteome Res. 17(3):961-977.

Cox J, Hein MY, Luber CA, Paron I, Nagaraj N, Mann M. 2014. Accurate proteome-wide label-free quantification by delayed normalization and maximal peptide ratio extraction, termed maxlfq. Mol Cell Proteomics. 13(9):2513-2526.

Denes BJ, Lagou A, Dorotheou D, Kiliaridis S. 2018. A longitudinal study on timing and velocity of rat molar eruption: Timing of rat molar eruption. Lab Anim. 52(4):394-401.

Eriksson M, Brown WT, Gordon LB, Glynn MW, Singer J, Scott L, Erdos MR, Robbins CM, Moses TY, Berglund P et al. 2003. Recurrent de novo point mutations in lamin a cause hutchinson-gilford progeria syndrome. Nature. 423(6937):293-298.

Giaimo BD, Borggrefe T. 2018. Introduction to molecular mechanisms in notch signal transduction and disease pathogenesis. Adv Exp Med Biol. 1066:3-30. 
Hilton MJ, Tu X, Wu X, Bai S, Zhao H, Kobayashi T, Kronenberg HM, Teitelbaum SL, Ross FP, Kopan R et al. 2008. Notch signaling maintains bone marrow mesenchymal progenitors by suppressing osteoblast differentiation. Nat Med. 14(3):306-314.

Hu B, Castillo E, Harewood L, Ostano P, Reymond A, Dummer R, Raffoul W, Hoetzenecker W, Hofbauer GF, Dotto GP. 2012. Multifocal epithelial tumors and field cancerization from loss of mesenchymal csl signaling. Cell. 149(6):1207-1220.

Hu B, Lefort K, Qiu W, Nguyen BC, Rajaram RD, Castillo E, He F, Chen Y, Angel P, Brisken C et al. 2010. Control of hair follicle cell fate by underlying mesenchyme through a cslwnt5a-foxn1 regulatory axis. Genes Dev. 24(14):1519-1532.

Kopan R, Ilagan MX. 2009. The canonical notch signaling pathway: Unfolding the activation mechanism. Cell. 137(2):216-233.

Kurpinski K, Lam H, Chu J, Wang A, Kim A, Tsay E, Agrawal S, Schaffer DV, Li S. 2010. Transforming growth factor-beta and notch signaling mediate stem cell differentiation into smooth muscle cells. Stem Cells. 28(4):734-742.

Li J, Feng J, Liu Y, Ho TV, Grimes W, Ho HA, Park S, Wang S, Chai Y. 2015. Bmp-shh signaling network controls epithelial stem cell fate via regulation of its niche in the developing tooth. Dev Cell. 33(2):125-135.

Li Y, Li SQ, Gao YM, Li J, Zhang B. 2014. Crucial role of notch signaling in osteogenic differentiation of periodontal ligament stem cells in osteoporotic rats. Cell Biol Int. $38(6): 729-736$.

Lin F, Worman HJ. 1993. Structural organization of the human gene encoding nuclear lamin A and nuclear lamin C. J Biol Chem. 268(22):16321-16326.

Lovschall H, Mitsiadis TA, Poulsen K, Jensen KH, Kjeldsen AL. 2007. Coexpression of notch3 and rgs5 in the pericyte-vascular smooth muscle cell axis in response to pulp injury. Int J Dev Biol. 51(8):715-721. 
Mitsiadis TA, Caton J, Pagella P, Orsini G, Jimenez-Rojo L. 2017. Monitoring notch signalingassociated activation of stem cell niches within injured dental pulp. Front Physiol. 8:372.

Nakao A, Kajiya H, Fukushima H, Fukushima A, Anan H, Ozeki S, Okabe K. 2009. Pthrp induces notch signaling in periodontal ligament cells. J Dent Res. 88(6):551-556.

Ono W, Sakagami N, Nishimori S, Ono N, Kronenberg HM. 2016. Parathyroid hormone receptor signalling in osterix-expressing mesenchymal progenitors is essential for tooth root formation. Nat Commun. 7:11277.

Osathanon T, Manokawinchoke J, Nowwarote N, Aguilar P, Palaga T, Pavasant P. 2013. Notch signaling is involved in neurogenic commitment of human periodontal ligamentderived mesenchymal stem cells. Stem Cells Dev. 22(8):1220-1231.

Rios HF, Ma D, Xie Y, Giannobile WV, Bonewald LF, Conway SJ, Feng JQ. 2008. Periostin is essential for the integrity and function of the periodontal ligament during occlusal loading in mice. J Periodontol. 79(8):1480-1490.

Rygh P, Bowling K, Hovlandsdal L, Williams S. 1986. Activation of the vascular system: A main mediator of periodontal fiber remodeling in orthodontic tooth movement. Am J Orthod. 89(6):453-468.

Singer D, Thamm K, Zhuang H, Karbanova J, Gao Y, Walker JV, Jin H, Wu X, Coveney CR, Marangoni P et al. 2019. Prominin-1 controls stem cell activation by orchestrating ciliary dynamics. EMBO J. 38(2).

Steele-Perkins G, Butz KG, Lyons GE, Zeichner-David M, Kim HJ, Cho MI, Gronostajski RM. 2003. Essential role for nfi-c/ctf transcription-replication factor in tooth root development. Mol Cell Biol. 23(3):1075-1084.

Takahashi A, Nagata M, Gupta A, Matsushita Y, Yamaguchi T, Mizuhashi K, Maki K, Ruellas AC, Cevidanes LS, Kronenberg HM et al. 2019. Autocrine regulation of mesenchymal 
progenitor cell fates orchestrates tooth eruption. Proc Natl Acad Sci U S A. 116(2):575580.

Tyanova S, Temu T, Sinitcyn P, Carlson A, Hein MY, Geiger T, Mann M, Cox J. 2016. The perseus computational platform for comprehensive analysis of (prote)omics data. Nat Methods. 13(9):731-740.

Vandevska-Radunovic V, Kristiansen AB, Heyeraas KJ, Kvinnsland S. 1994. Changes in blood circulation in teeth and supporting tissues incident to experimental tooth movement. Eur J Orthod. 16(5):361-369.

Walker JV, Zhuang H, Singer D, Illsley CS, Kok WL, Sivaraj KK, Gao Y, Bolton C, Liu Y, Zhao M et al. 2019. Transit amplifying cells coordinate mouse incisor mesenchymal stem cell activation. Nature Communications. In press. ${ }^{* *}$ (Needs update prior to publication)

Worman HJ. 2012. Nuclear lamins and laminopathies. J Pathol. 226(2):316-325.

Zhang C, Chang J, Sonoyama W, Shi S, Wang CY. 2008. Inhibition of human dental pulp stem cell differentiation by notch signaling. J Dent Res. 87(3):250-255. 


\section{Figure legends}

\section{Figure 1. PDL express distinct molecular signatures upon occlusion establishment}
A: Hematoxylin-Eosin (HE) staining of the P18 and P28 rat first lower molar.
B: Goldner staining of P18 and P28 PDL regions. Note the green-blue stained collagen fibers are abundant at P28 but not P18.

C: Immunofluorescent staining of Periostin with a specific antibody raised in rabbit then visualised using anti-Rabbit Alexa 568 (red) conjugated secondary antibody. Note the significantly increased Periostin signal at P28 comparing to P18.

D: Gene function enrichment analysis on the RNAseq results by comparing P28 with P18 PDL.

E, F: Differential analysis performed on the RNAseq results by comparing P28 with P18 PDL.

E: Metacore Pathway Maps heatmaps analysis.

D: GO analysis for the biological processes.

Bars: A: $100 \mu \mathrm{m} ; \mathrm{B}, \mathrm{C}: 20 \mu \mathrm{m}$.

\section{Figure 2. Notch signalling has dynamic changes during PDL maturation}
A: String analysis of the genes of top 10 pathways of the metacore Pathway Maps of the RNAseq results.
B: Metacore Pathway Maps analysis.
C: String analysis of the genes of top 10 pathways of the metacore Pathway Maps.
D: Notch pathway members that had significant changes in the RNAseq analysis. 
D-H: Immunofluorescent analysis of the indicated molecules using specific primary antibodies. The Alexa 488 (green) or 568 (red) conjugated secondaries were used to identify the primary antibodies. Dotted lines mark the boundary between PDL and bone (B) or dentin (D). Bars: $20 \mu \mathrm{m}$

\section{Figure 3. Intercepting canonical Notch pathway delayed PDL maturation}

A: Immunostaining PDL of the second lower molars from P21 RBP-Jk flox/flox (control) and Collagen 1a2 Cre x RBP-Jk flox/flox (cKO) mice. Note the Cre positive signal could only be observed in the cKO mice.

B: HE staining of the P21 control and cKO mice second lower molars. Stars: PDL.

C, D: Stereo images of 1 month old control and cKO mouse mandibles and first lower molars. Note the cKO mouse tooth's crown size are smaller and roots are shorter than the control.

E: Representative stereo images of the first and third lower molars of the control and cKO mice at postnatal day 14 .

F: Representative micro-CT analysis of the control and cKO fist lower molar eruption from 4 months old animals.

G: First lower molar mesial buccal root length comparisation at P14 and 2 months. $* * \mathrm{p}<0.01$. H-J: Immunofluorescent analysis of Periostin using specific primary followed by secondary antibodies (Alexa 568, red) at indicated stages. Note comparing to the controls, RBP-Jkappa cKO mouse PDL has delayed expression of Periostin at P10 and P14, but not at 2 months. Bars: A, B, H-J: $20 \mu \mathrm{m}$; C-F: $1 \mathrm{~mm}$.

Figure 4. Stretching force induced Notch pathway activation and matrix protein productions on a human PDL cell line. 


\begin{abstract}
A and B: Real time RT-PCR analysis on human PDL cells at a ratio of $20 \%$ stretching and frequency of 30x/min. Samples were collected after 12 hours. ${ }^{* *} \mathrm{p}<0.01$.

C: Metacore analysis of proteomic analysis on the samples of A and B.

D: String analysis of the top 5 pathways affected by stretching force.
\end{abstract}

\title{
Figure 5. Lamin A is a marker of PDL maturation and is under the control of Notch pathway.
}

A: Compound analysis of the common targets from the in vivo RNAseq (Figure 1) and proteomic and in vitro cell stretching results (Figure 4). Note Lamin A (LMNA) is the only molecule that was commonly regulated in the three conditions.

B: Immunofluorescent analysis of Lamin A/C expression in the P18 vs. P28 PDL. D: Dentin;

B: Bone; Dotted lines: boundaries.

C: Western blotting analysis of Lamin A/C expression in the human PDL cells upon stretching (Figure 4 A\&B), with GapDH as the loading control. Note only Lamin A expression was significantly changed.

D: Western blotting analysis of Lamin A/C expression in the human PDL cells treated with Jagged1, with GapDH as the loading control. Note again only Lamin A expression was significantly changed.

$\mathrm{E}$ and F: Immunofluorescent analysis of Lamin A/C expression in the control and $\mathrm{cKO}$ mouse PDL at P10 and 2 months. D: Dentin; B: Bone; Dotted lines: boundaries.

Bars: $20 \mu \mathrm{m}$ 
A

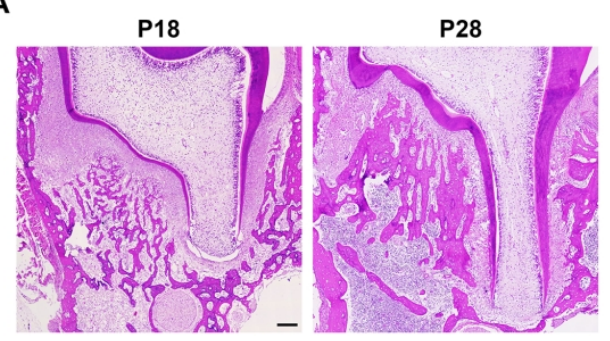

C

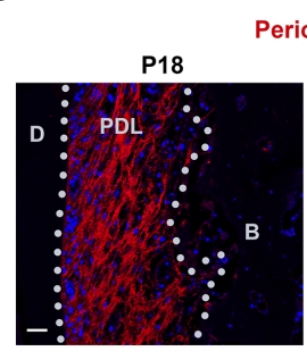

E

Metacore pathway maps enrichment $\begin{array}{ll}-2 & 0 \\ \text { Row Z-Score } & 2\end{array}$

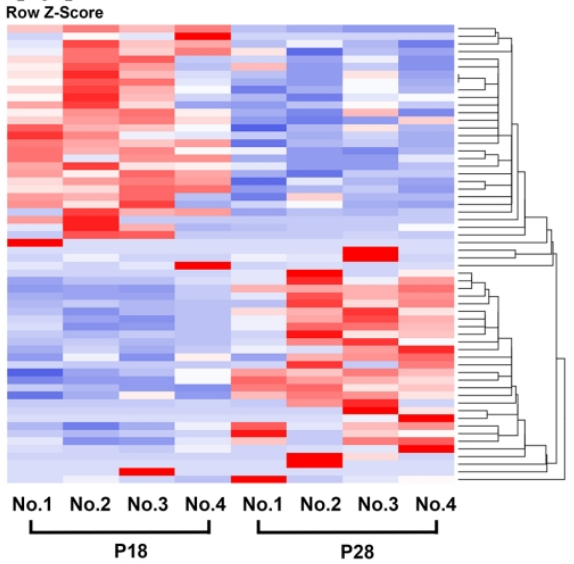

B

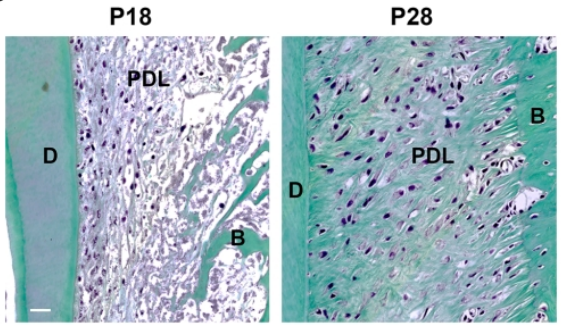

D

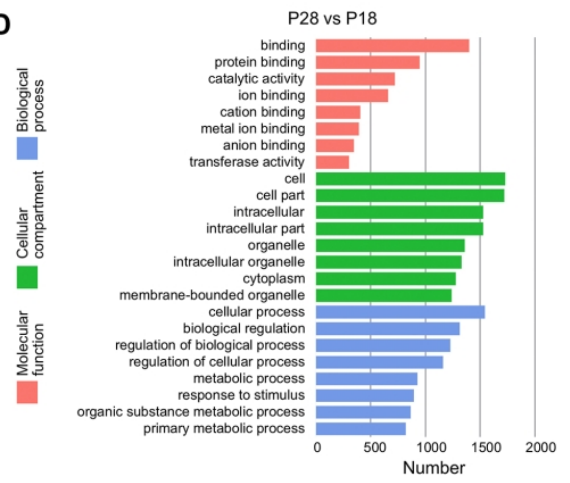

F

\begin{tabular}{llc}
\hline & GO Biological Process & pValue \\
\hline 1 & Biomineral tissue development (GO:0031214) & $2.68 \mathrm{E}-02$ \\
\hline 2 & Muscle contraction (GO:0006936) & $6.77 \mathrm{E}-03$ \\
\hline 3 & Muscle system process (GO:0003012) & $6.76 \mathrm{E}-04$ \\
\hline 4 & $\begin{array}{l}\text { Regulation of neurotransmitter levels } \\
\text { (GO:0001505) }\end{array}$ & $2.67 \mathrm{E}-03$ \\
\hline 5 & Response to metal ion (GO:0010038) & $8.46 \mathrm{E}-04$ \\
\hline 6 & Cell adhesion (GO:0007155) & $5.98 \mathrm{E}-06$ \\
\hline 7 & Positive regulation of cell migration (GO:0030335) & $8.72 \mathrm{E}-04$ \\
\hline 8 & Biological adhesion (GO:0022610) & $1.12 \mathrm{E}-05$ \\
\hline 9 & Response to steroid hormone (GO:0048545) & $7.99 \mathrm{E}-03$ \\
\hline 10 & Positive regulation of cell motility (GO:2000147) & $1.03 \mathrm{E}-03$ \\
\hline
\end{tabular}

Figure 1

$182 \times 227 \mathrm{~mm}(300 \times 300 \mathrm{DPI})$

http://mc.manuscriptcentral.com/jdr 
A

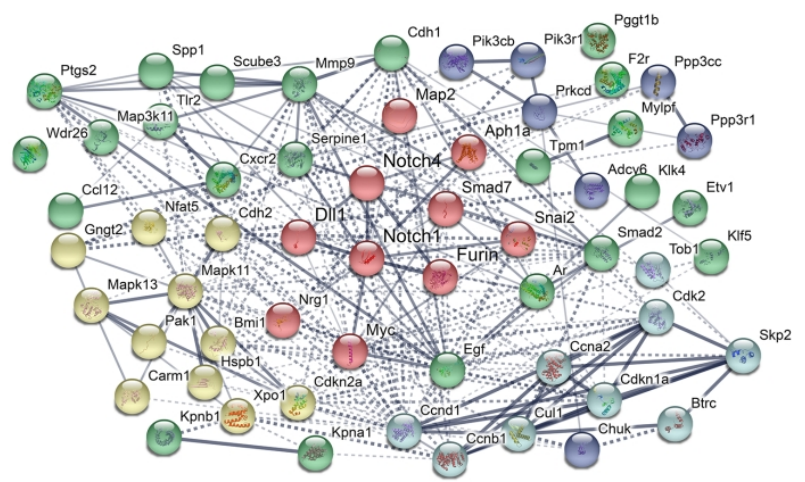

B

D

\begin{tabular}{|c|c|c|}
\hline & Pathway Maps & pValue \\
\hline 1 & $\mathrm{PI} 3 \mathrm{~K}$ signaling in gastric cancer & $6.44 E-08$ \\
\hline 2 & Notch signaling in breast cancer & $1.18 \mathrm{E}-07$ \\
\hline 3 & $\begin{array}{l}\text { Cell cycle - Nucleocytoplasmic transport of } \\
\text { CDK/Cyclins }\end{array}$ & $6.08 \mathrm{E}-07$ \\
\hline 4 & $\begin{array}{l}\text { Inhibition of TGF-beta } 1 \text { signaling in early colorectal } \\
\text { cancer }\end{array}$ & $3.59 E-06$ \\
\hline 5 & $\begin{array}{l}\text { Cell cycle - Influence of Ras and Rho proteins on } \\
\text { G1/S Transition }\end{array}$ & $4.30 \mathrm{E}-06$ \\
\hline
\end{tabular}

C

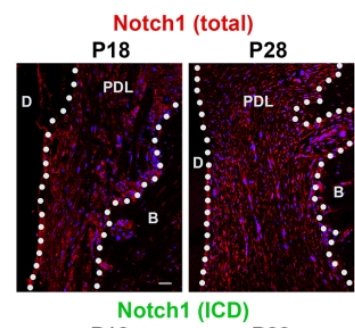

\begin{tabular}{lll}
\hline Gene & Fold change & pValue \\
\hline Notch1 & 2.08 & 0.011 \\
\hline Notch4 & 2.11 & 0.018 \\
\hline Dll1 & 7.19 & 0.031 \\
\hline Jag1 & 2.52 & 0.067 \\
\hline Furin & 0.5 & 0.000 \\
\hline
\end{tabular}

E

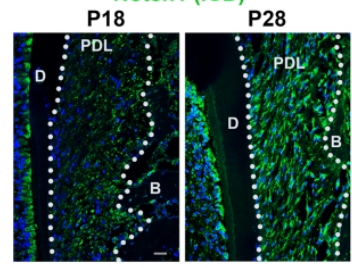

F

DII1

G Osteopontin

H P18 $^{\text {Notch2 (ICD) }}$
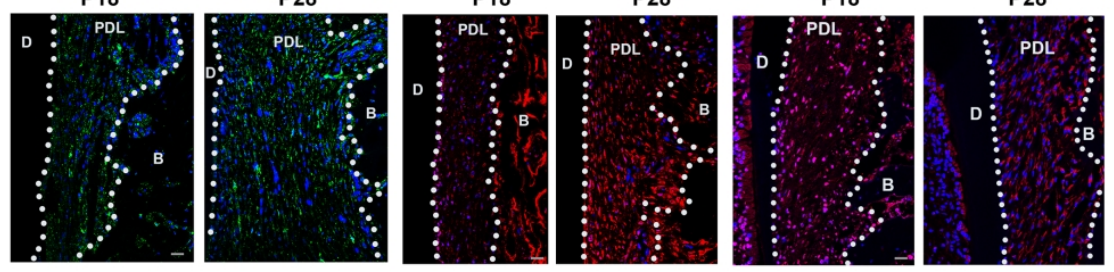

Figure 2

$184 \times 252 \mathrm{~mm}(300 \times 300 \mathrm{DPI})$ 

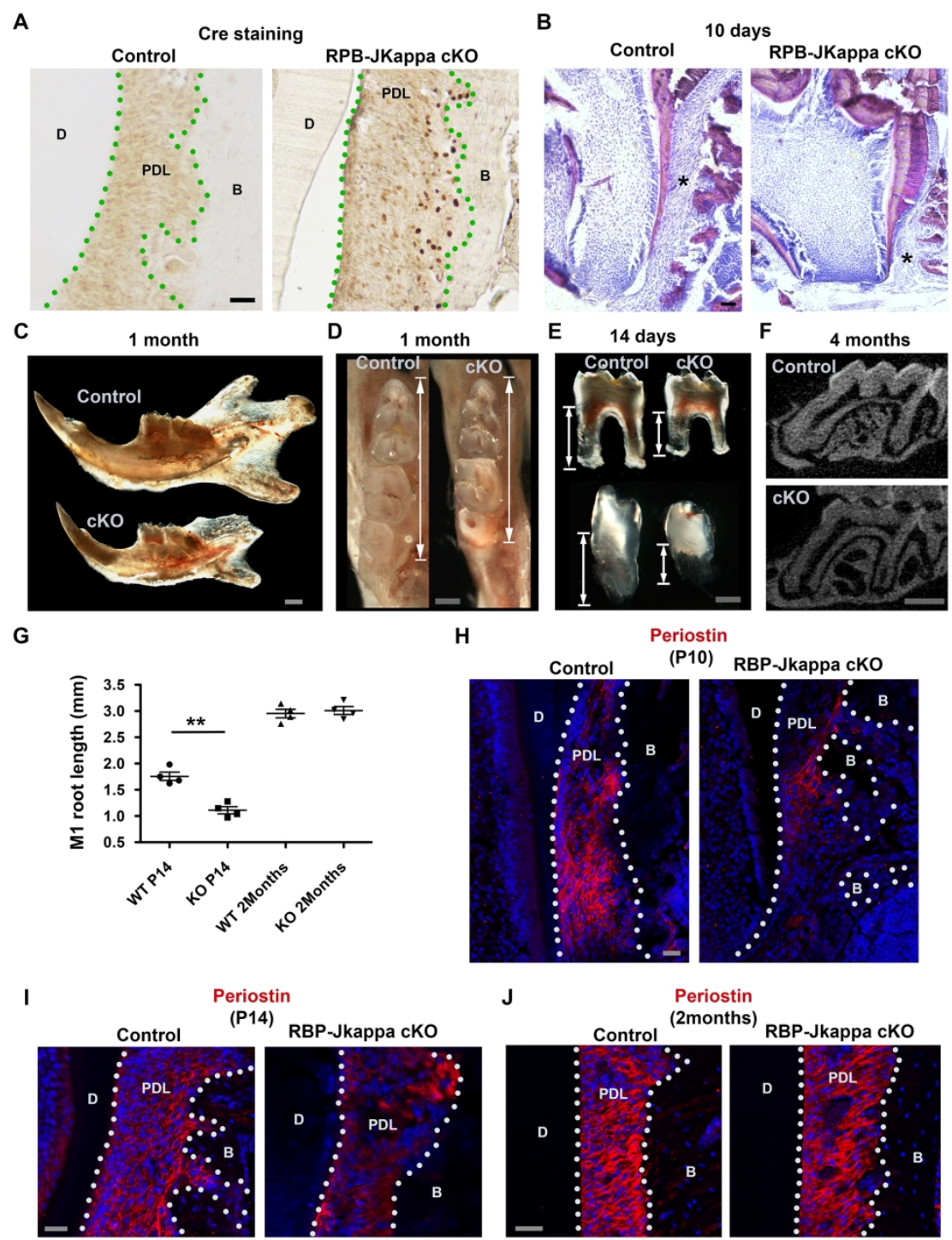

Figure 3 
A In vitro human PDL cell
stretching experiments
B

In vitro human PDL cell stretching experiments

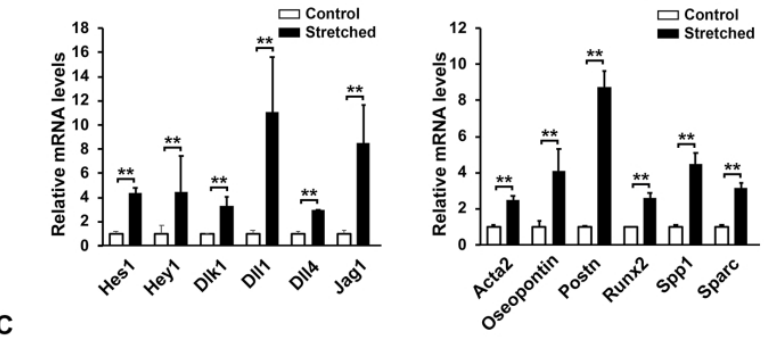

\begin{tabular}{|c|c|c|}
\hline & Pathway maps & pValue \\
\hline$\overline{1}$ & $\begin{array}{l}\text { Cytoskeleton remodeling - Regulation of actin cytoskeleton organization by } \\
\text { the kinase effectors of Rho GTPases }\end{array}$ & $8.67 \mathrm{E}-06$ \\
\hline 2 & Role of stellate cells in progression of pancreatic cancer & $1.09 \mathrm{E}-05$ \\
\hline 3 & $\begin{array}{l}\text { Cytoskeleton remodeling - Regulation of actin cytoskeleton nucleation and } \\
\text { polymerization by Rho GTPases }\end{array}$ & $2.48 \mathrm{E}-05$ \\
\hline 4 & $\begin{array}{l}\text { Th2 cytokine- and TNF-alpha-induced profibrotic response in asthmatic } \\
\text { airway fibroblasts/myofibroblasts }\end{array}$ & $5.06 \mathrm{E}-05$ \\
\hline 5 & $\begin{array}{l}\text { Development - Regulation of cytoskeleton proteins in oligodendrocyte } \\
\text { di } \_ \text {erentiation and myelination }\end{array}$ & $9.45 \mathrm{E}$ \\
\hline 6 & $\begin{array}{l}\text { IL-1 beta- and Endothelin-1-induced fibroblast/ myofibroblast migration and } \\
\text { extracellular matrix production in asthmatic airways }\end{array}$ & $1.49 \mathrm{E}$ \\
\hline 7 & $\begin{array}{l}\text { TGF-beta-induced fibroblast/ myofibroblast migration and extracellular matrix } \\
\text { production in asthmatic airways }\end{array}$ & $1.64 \mathrm{E}-04$ \\
\hline 8 & Cytoskeleton remodeling - Hyaluronic acid/ CD44 signaling pathways & $2.12 \mathrm{E}-04$ \\
\hline 9 & Histidine-glutamate-glutamine metabolism & $2.29 \mathrm{E}-04$ \\
\hline 10 & Transport - Clathrin-coated vesicle cycle & $2.92 \mathrm{E}-04$ \\
\hline
\end{tabular}

D

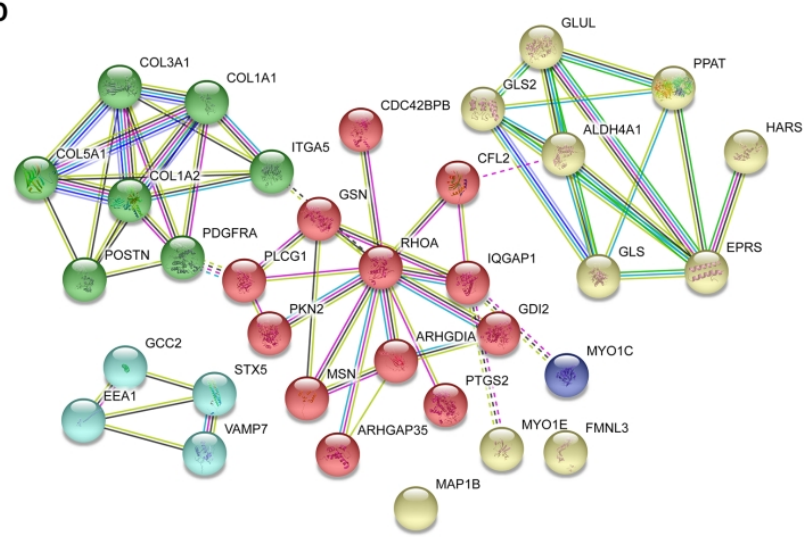

Figure 4 
A

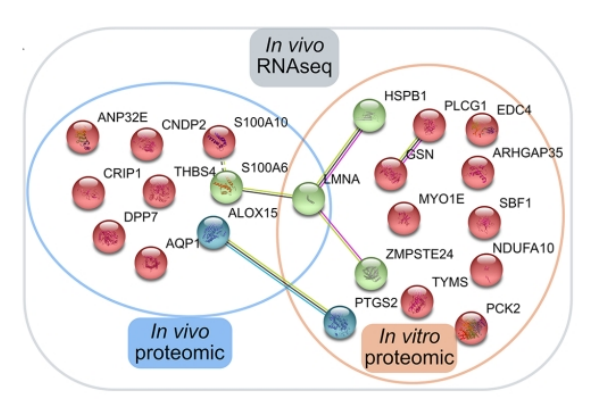

C

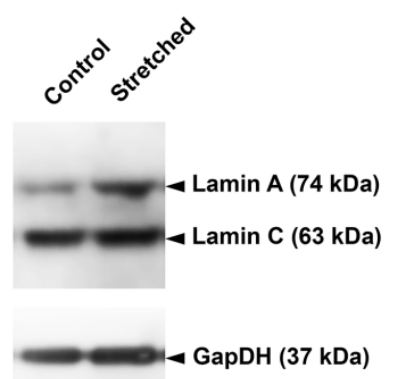

E

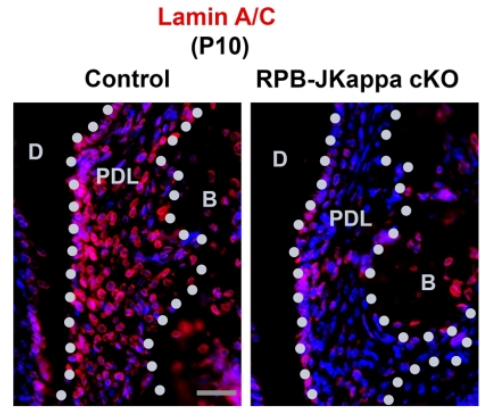

B

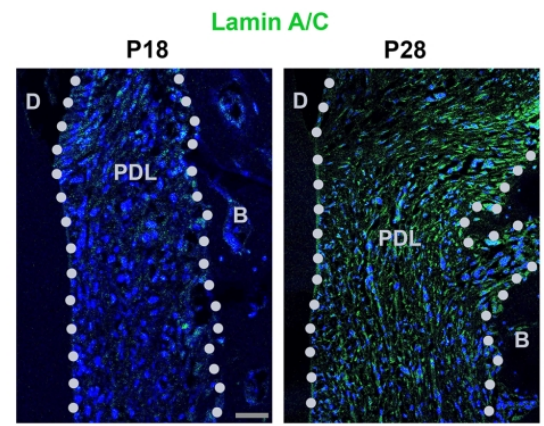

D

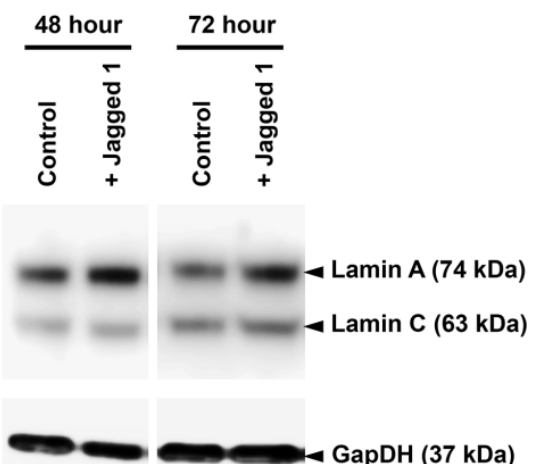

$\mathbf{F}$

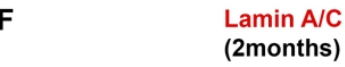

Lamin A/C

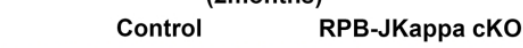

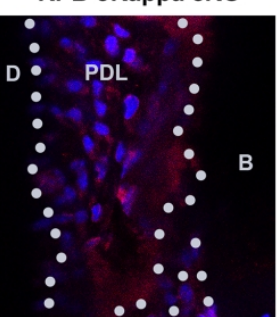

Figure 5

$176 \times 227 \mathrm{~mm}(300 \times 300$ DPI $)$ 


\title{
Notch coordinates periodontal ligament maturation through regulating Lamin $\mathbf{A}$
}

\author{
Balazs Jozsef Denes ${ }^{1}$, Chloe Bolton², Charlotte Sara Illsley², Wai Ling Kok², Jemma Victoria \\ Walker ${ }^{2}$, Ansgar Poetsch ${ }^{3}$, Christopher Tredwin ${ }^{2}$, Stavros Kiliaridis ${ }^{1}, \mathrm{Bing}_{\mathrm{Hu}}^{2}{ }^{*}$
}

\section{Appendix files and legends}

\section{Appendix Figure 1}

A: Additional micro-CT analysis on P18 and P28 rat root.

B: Additional process network analysis on the RNAseq results illustrated in Figure 1.

Bar: $100 \mu \mathrm{m}$

\section{Appendix Figure 2}

A: Periostin expression analysis at postnatal day $4(\mathrm{P} 4)$ in the control and RBP-Jkappa cKO mice.

B: The stretching device system used in this study.

Bar: $20 \mu \mathrm{m}$

\section{Appendix Figure 3}

Summarisation of the findings of study and perspectives.

\section{Appendix Table 1}

The RNAseq summary of the study.

\section{Appendix Table 2}


The original proteomic analysis data of stretched PDL cells showed in Figure 4.

\section{Appendix Table 3}

The antibodies, primers and protein used in the study.

A

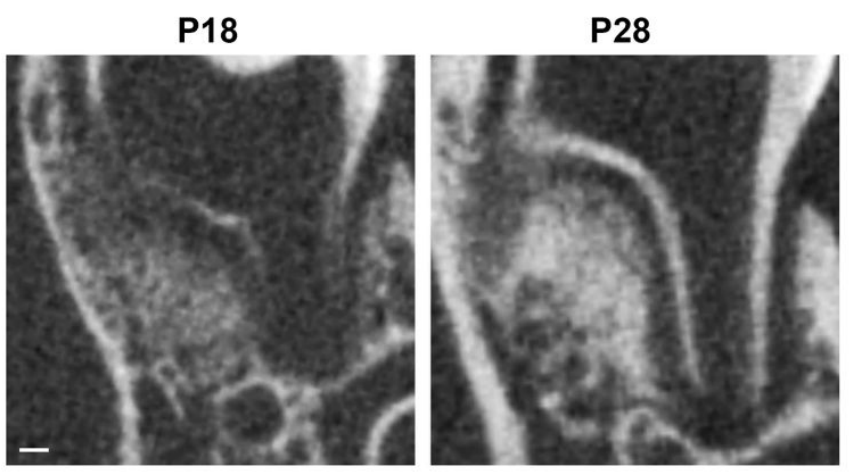

B

\begin{tabular}{llc}
\hline & Process networks & pValue \\
\hline $\mathbf{1}$ & Development - Neurogenesis - Axonal guidance & $2.80 \mathrm{E}-04$ \\
\hline $\mathbf{2}$ & Development - Ossification and bone remodeling & $3.14 \mathrm{E}-04$ \\
\hline $\mathbf{3}$ & Muscle contraction & $3.69 \mathrm{E}-04$ \\
\hline $\mathbf{4}$ & $\begin{array}{l}\text { Signal Transduction - TGF-beta, GDF and Activin } \\
\text { signaling }\end{array}$ & $5.06 \mathrm{E}-04$ \\
\hline $\mathbf{5}$ & Cell adhesion - Cell junctions & $5.47 \mathrm{E}-04$ \\
\hline $\mathbf{6}$ & Cell cycle - G1-S Growth factor regulation & $7.53 \mathrm{E}-04$ \\
\hline $\mathbf{7}$ & Signal transduction - NOTCH signaling & $8.64 \mathrm{E}-04$ \\
\hline $\mathbf{8}$ & Inflammation - IFN-gamma signaling & $9.05 \mathrm{E}-04$ \\
\hline $\mathbf{9}$ & Development - Blood vessel morphogenesis & $9.24 \mathrm{E}-04$ \\
\hline $\mathbf{1 0}$ & Proliferation - Positive regulation cell proliferation & $9.86 \mathrm{E}-04$ \\
\hline
\end{tabular}

\section{Appendix Figure 1}


A

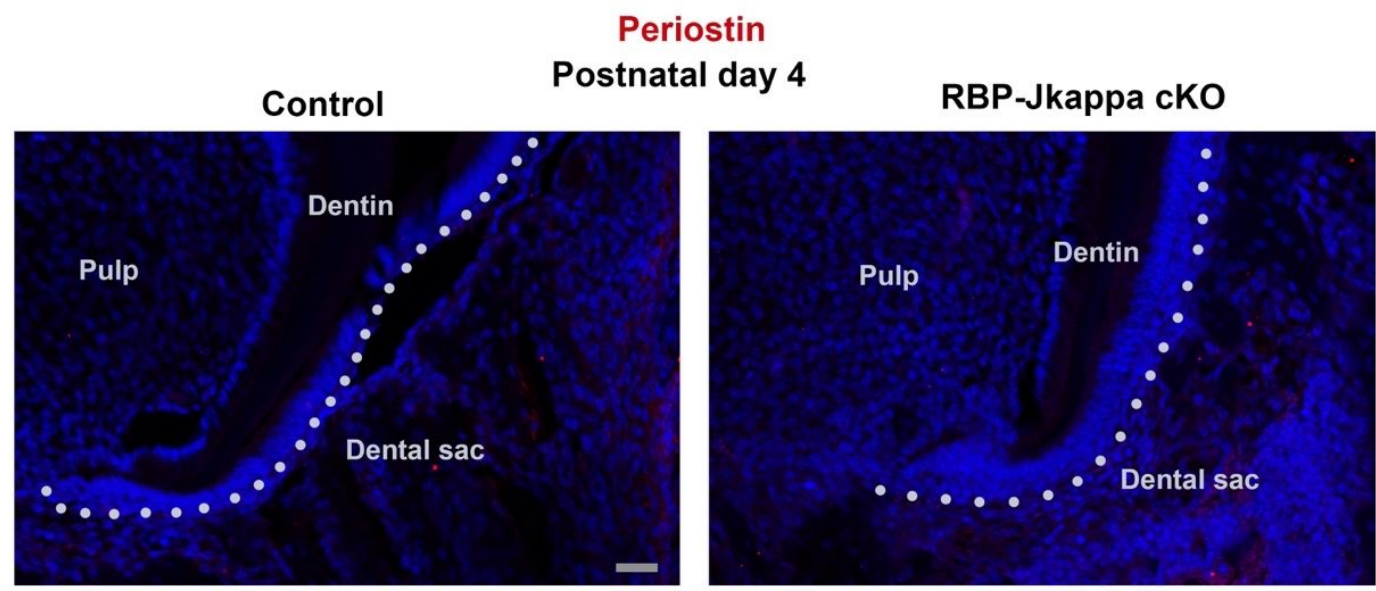

B

C

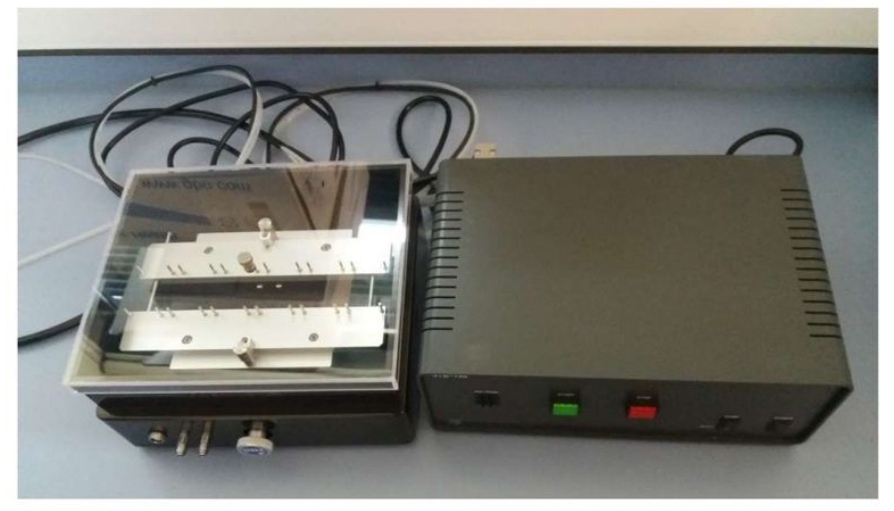

Stretching unit Controlling unit

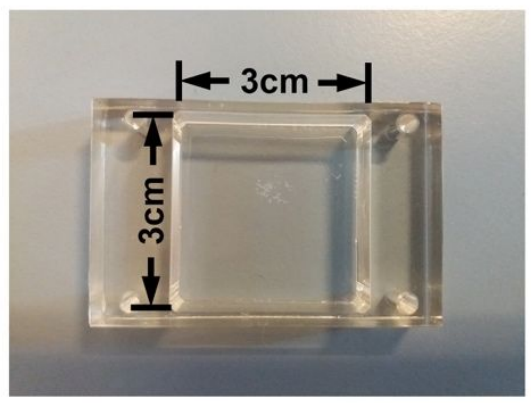

Stretching chamber

Appendix Figure 2 


\section{Appendix Figure 3}




\section{Appendix Table 1}

Summary of the fold changes of the genes up and down regulated comparing P28 with P18 PDL based on the RNAseq analysis results as showed in Figure 1D. The genes inside the category of "Cell" has been shown as below.

\begin{tabular}{|c|c|c|}
\hline A4galt & 56.2 & 0.012 \\
\hline Aak1 & -6.2 & 0.046 \\
\hline Aatf & -3.0 & 0.001 \\
\hline Abca2 & 4.4 & 0.001 \\
\hline Abca4 & -27.3 & 0.034 \\
\hline Abca7 & 5.6 & 0.036 \\
\hline$A b c c 2$ & -29.1 & 0.037 \\
\hline$A b c c 5$ & 2.9 & 0.006 \\
\hline$A b c d 3$ & 2.5 & 0.023 \\
\hline Abce1 & -2.0 & 0.001 \\
\hline Abi1 & 1.7 & 0.008 \\
\hline Abi3 & 2.6 & 0.005 \\
\hline Abt1 & 1.5 & 0.046 \\
\hline Acads & 1.6 & 0.038 \\
\hline$A c b d 3$ & 2.1 & 0.032 \\
\hline Acer1 & 60.2 & 0.042 \\
\hline Ache & -10.8 & 0.013 \\
\hline Ache & -10.8 & 0.013 \\
\hline Ackr2 & 840.3 & 0.003 \\
\hline Ackr3 & 2.7 & 0.006 \\
\hline Acot11 & -122.2 & 0.039 \\
\hline Acox 1 & -5.4 & 0.016 \\
\hline Acp5 & 12.7 & 0.001 \\
\hline Acsbg 1 & 77.1 & 0.038 \\
\hline Acta2 & -4.2 & 0.004 \\
\hline Actr10 & -1.6 & 0.022 \\
\hline Actr3 & -1.9 & 0.017 \\
\hline Acvr1b & 24.5 & 0.044 \\
\hline Adam19 & -1.8 & 0.044 \\
\hline Adamts15 & 32.3 & 0.036 \\
\hline Adcy10 & 89.7 & 0.015 \\
\hline Adcy 6 & 2.4 & 0.029 \\
\hline Adcyap1r1 & 23.1 & 0.022 \\
\hline Adh4 & 16.2 & 0.046 \\
\hline Adh5 & -1.5 & 0.020 \\
\hline Adh6a & -126.0 & 0.020 \\
\hline Adh7 & 1517.8 & 0.003 \\
\hline Adm & -10.4 & 0.000 \\
\hline Adpgk & -1.6 & 0.016 \\
\hline
\end{tabular}




\begin{tabular}{|c|c|c|}
\hline Adra1b & 28.5 & 0.032 \\
\hline Adrb1 & -59.2 & 0.048 \\
\hline Adsl & -1.9 & 0.003 \\
\hline$A f g 3 / 2$ & -1.7 & 0.048 \\
\hline Aga & 1.7 & 0.009 \\
\hline Agpat4 & -2.3 & 0.002 \\
\hline Agps & -2.9 & 0.042 \\
\hline Ahnak & 2.2 & 0.032 \\
\hline Aif1l & -8.4 & 0.016 \\
\hline$A k 1$ & -1.9 & 0.015 \\
\hline Akap12 & 2.2 & 0.018 \\
\hline Akap17a & 2.6 & 0.021 \\
\hline Akap5 & -158.1 & 0.017 \\
\hline Akap8I & 2.4 & 0.001 \\
\hline Akip1 & 1.9 & 0.013 \\
\hline Alad & -1.8 & 0.045 \\
\hline Alas2 & -5.7 & 0.012 \\
\hline Aldh1a3 & -73.2 & 0.017 \\
\hline Aldh1b1 & -159.0 & 0.002 \\
\hline Aldh1/1 & -9.6 & 0.031 \\
\hline Aldh6a1 & -1.8 & 0.013 \\
\hline Alg11 & -3.1 & 0.000 \\
\hline Alg2 & -2.6 & 0.004 \\
\hline Alk & 339.8 & 0.006 \\
\hline Alox15 & -11.1 & 0.001 \\
\hline Als2 & -11.3 & 0.032 \\
\hline Amelx & -88.0 & 0.006 \\
\hline Amigo1 & -147.1 & 0.025 \\
\hline Ampd1 & 60.5 & 0.011 \\
\hline Amph & -19.5 & 0.036 \\
\hline Anapc1 & -1.7 & 0.033 \\
\hline Anapc5 & -1.6 & 0.001 \\
\hline Angpt/6 & 49.7 & 0.023 \\
\hline Ankhd1 & 2.1 & 0.011 \\
\hline Ankrd13a & -1.8 & 0.010 \\
\hline Ankrd23 & 22.9 & 0.036 \\
\hline Anp32e & -2.7 & 0.000 \\
\hline Aox3 & 31.0 & 0.032 \\
\hline Ap1s2 & -1.7 & 0.026 \\
\hline$A p 2 m 1$ & -1.7 & 0.003 \\
\hline Aph1a & -2.3 & 0.001 \\
\hline Api5 & -1.7 & 0.004 \\
\hline Apoc3 & 55.0 & 0.011 \\
\hline Aqp1 & 2.7 & 0.015 \\
\hline Aqp3 & 211.9 & 0.001 \\
\hline Aqp4 & 1752.4 & 0.001 \\
\hline
\end{tabular}




\begin{tabular}{|c|c|c|}
\hline$A r$ & 20.5 & 0.005 \\
\hline$A r$ & 20.5 & 0.005 \\
\hline$A r$ & 20.5 & 0.005 \\
\hline$A r$ & 20.5 & 0.005 \\
\hline Arcn1 & -1.9 & 0.001 \\
\hline $\operatorname{Arf1}$ & -1.8 & 0.021 \\
\hline Arf2 & -1.9 & 0.017 \\
\hline Arf4 & -1.5 & 0.004 \\
\hline Arfip1 & -2.6 & 0.007 \\
\hline Arfip2 & 2.3 & 0.003 \\
\hline $\operatorname{Arg} 2$ & 5.8 & 0.000 \\
\hline Arglu1 & 2.0 & 0.028 \\
\hline Arhgap35 & 1.9 & 0.047 \\
\hline Arhgap4 & -4.8 & 0.027 \\
\hline Arhgef18 & -1.9 & 0.037 \\
\hline Arhgef25 & -1.8 & 0.013 \\
\hline Arhgef7 & -1.7 & 0.037 \\
\hline Arl1 & -2.6 & 0.001 \\
\hline Arl3 & 1.6 & 0.015 \\
\hline Arl6ip1 & -1.6 & 0.050 \\
\hline Arntl & 2.3 & 0.025 \\
\hline Arnt/2 & -85.0 & 0.036 \\
\hline Arrdc1 & 1.6 & 0.009 \\
\hline Arsi & 7.2 & 0.019 \\
\hline Asgr2 & 178.3 & 0.002 \\
\hline Ash1l & 2.0 & 0.039 \\
\hline Asic1 & 79.2 & 0.023 \\
\hline Asip & 71.8 & 0.027 \\
\hline Atad1 & -2.0 & 0.021 \\
\hline Ate1 & 1.9 & 0.016 \\
\hline Atf4 & 1.6 & 0.012 \\
\hline Atic & -2.8 & 0.000 \\
\hline At/2 & -4.1 & 0.031 \\
\hline Atoh8 & 3.6 & 0.001 \\
\hline Atp1a3 & -52.7 & 0.032 \\
\hline Atp2a2 & -1.6 & 0.010 \\
\hline Atp $2 b 2$ & 98.2 & 0.013 \\
\hline Atp2b3 & 36.5 & 0.049 \\
\hline Atp2b4 & 1.9 & 0.038 \\
\hline Atp5e & 2.0 & 0.030 \\
\hline Atp5i & 1.7 & 0.039 \\
\hline Atp5j2 & 1.7 & 0.029 \\
\hline Atp6v0b & 2.4 & 0.001 \\
\hline Atp6v1e1 & 1.7 & 0.005 \\
\hline Atp6v1e2 & 164.2 & 0.017 \\
\hline Atp6v1f & 1.8 & 0.001 \\
\hline
\end{tabular}




\begin{tabular}{|c|c|c|}
\hline Atxn10 & -2.2 & 0.000 \\
\hline Avil & 417.1 & 0.000 \\
\hline Avp & 183.0 & 0.008 \\
\hline Azin 2 & 5.5 & 0.028 \\
\hline$B 2 m$ & 2.0 & 0.002 \\
\hline B3galnt1 & -1.6 & 0.040 \\
\hline B3galt1 & -264.1 & 0.037 \\
\hline B3galt2 & -43.4 & 0.012 \\
\hline B3galt6 & -3.0 & 0.018 \\
\hline B3gat3 & 1.9 & 0.001 \\
\hline B4galnt4 & -13.4 & 0.047 \\
\hline B4galt2 & -1.6 & 0.014 \\
\hline B4galt6 & 1.9 & 0.008 \\
\hline$B 9 d 2$ & 1.8 & 0.013 \\
\hline Bag3 & 1.8 & 0.042 \\
\hline Bag4 & -4.3 & 0.031 \\
\hline Batf & 3.3 & 0.017 \\
\hline Bbs2 & -2.0 & 0.043 \\
\hline Bche & -122.2 & 0.031 \\
\hline Bckdhb & -1.9 & 0.003 \\
\hline$B c / 2 / 15$ & 42.5 & 0.050 \\
\hline$B c 16$ & 4.9 & 0.002 \\
\hline Bcorl1 & 2.4 & 0.034 \\
\hline Bglap & 4.6 & 0.003 \\
\hline Blk & -17.9 & 0.002 \\
\hline Bloc1s1 & 1.6 & 0.037 \\
\hline$B l z f 1$ & -2.2 & 0.036 \\
\hline Bmi1 & -7.3 & 0.013 \\
\hline Bmpr1a & -3.8 & 0.006 \\
\hline$B m x$ & -30.0 & 0.013 \\
\hline Bod1 & 1.6 & 0.028 \\
\hline Brd9 & 1.7 & 0.043 \\
\hline Brf1 & -1.7 & 0.037 \\
\hline Bri3 & 2.4 & 0.009 \\
\hline Brinp1 & -42.1 & 0.000 \\
\hline Brinp2 & 121.9 & 0.003 \\
\hline Brms1l & -4.0 & 0.006 \\
\hline Btaf1 & 1.7 & 0.046 \\
\hline Btbd1 & -1.7 & 0.009 \\
\hline Btbd6 & -1.7 & 0.010 \\
\hline Btk & -7.5 & 0.014 \\
\hline Btnl2 & -63.2 & 0.022 \\
\hline Btrc & -2.8 & 0.015 \\
\hline Bub1 & -2.7 & 0.013 \\
\hline$B z w 1$ & -2.2 & 0.011 \\
\hline Bzw2 & -2.0 & 0.001 \\
\hline
\end{tabular}




\begin{tabular}{|c|c|c|}
\hline C1qa & 2.5 & 0.003 \\
\hline$c 1 q b$ & 1.9 & 0.041 \\
\hline$C 1 q c$ & 1.9 & 0.042 \\
\hline Cacna1c & -4.9 & 0.004 \\
\hline Cacna2d4 & 30.2 & 0.045 \\
\hline Cacnb4 & 74.6 & 0.018 \\
\hline Cacng6 & -137.5 & 0.026 \\
\hline Cadm1 & 4.0 & 0.003 \\
\hline Calb1 & -39.7 & 0.008 \\
\hline Calcb & -65.3 & 0.023 \\
\hline Calm3 & -1.5 & 0.037 \\
\hline Camk1g & 146.8 & 0.018 \\
\hline Camk2a & -34.6 & 0.047 \\
\hline Camk2d & -4.3 & 0.031 \\
\hline Capg & 2.9 & 0.001 \\
\hline Capn12 & 4.9 & 0.005 \\
\hline Capn15 & 2.6 & 0.026 \\
\hline Capn3 & -348.3 & 0.001 \\
\hline Caprin1 & -2.1 & 0.002 \\
\hline Capza1 & -1.9 & 0.002 \\
\hline Capza2 & -1.6 & 0.014 \\
\hline Carf & 15.0 & 0.025 \\
\hline Carm1 & -2.1 & 0.017 \\
\hline Casp1 & -4.0 & 0.017 \\
\hline Casp4 & 3.4 & 0.006 \\
\hline Casp7 & -3.6 & 0.008 \\
\hline Casp8 & -11.9 & 0.000 \\
\hline Cav3 & 72.1 & 0.044 \\
\hline Cbll1 & 1.9 & 0.003 \\
\hline$C b \times 7$ & 7.3 & 0.049 \\
\hline Ccar1 & 1.7 & 0.035 \\
\hline Ccdc22 & 3.9 & 0.024 \\
\hline Ccdc67 & -170.7 & 0.012 \\
\hline Ccdc69 & -20.1 & 0.032 \\
\hline Cchcr1 & 1.8 & 0.020 \\
\hline Ccl12 & 112.4 & 0.015 \\
\hline $\mathrm{Ccl} 21$ & 258.3 & 0.014 \\
\hline Ccna2 & -3.1 & 0.006 \\
\hline Ccnb1 & -2.1 & 0.026 \\
\hline Ccnb1ip1 & 427.6 & 0.003 \\
\hline Cond 1 & 2.1 & 0.025 \\
\hline Ccndbp1 & 1.9 & 0.004 \\
\hline Conh & -1.7 & 0.015 \\
\hline Cony & -1.9 & 0.042 \\
\hline Ccr7 & 44.0 & 0.046 \\
\hline Cct6a & -1.6 & 0.011 \\
\hline
\end{tabular}




\begin{tabular}{|c|c|c|}
\hline$C d 164$ & -1.8 & 0.001 \\
\hline$C d 177$ & -22.0 & 0.027 \\
\hline Cd19 & -64.0 & 0.004 \\
\hline$C d 22$ & -97.8 & 0.002 \\
\hline$C d 244$ & -34.9 & 0.016 \\
\hline$C d 320$ & 1.8 & 0.008 \\
\hline Cd36 & -10.9 & 0.017 \\
\hline$C d 38$ & -22.3 & 0.027 \\
\hline$C d 3 g$ & -10.1 & 0.032 \\
\hline $\mathrm{Cd} 44$ & 1.9 & 0.029 \\
\hline$C d 5$ & 92.0 & 0.023 \\
\hline Cd55 & 17.0 & 0.009 \\
\hline Cd68 & 3.0 & 0.013 \\
\hline$C d 69$ & -569.3 & 0.003 \\
\hline$C d 79 b$ & -6.2 & 0.017 \\
\hline$C d 9$ & 2.3 & 0.000 \\
\hline$C d 99$ & 2.0 & 0.014 \\
\hline Cdc123 & -1.7 & 0.005 \\
\hline$C d c 14 a$ & 3.2 & 0.013 \\
\hline$C d c 16$ & -2.2 & 0.000 \\
\hline$C d c 23$ & -2.0 & 0.011 \\
\hline$C d c 26$ & -2.7 & 0.000 \\
\hline$C d c 34$ & 1.7 & 0.026 \\
\hline$C d c 40$ & -1.8 & 0.028 \\
\hline Cdc6 & -4.8 & 0.015 \\
\hline Cdca 7 & -3.2 & 0.011 \\
\hline Cdh1 & 8.6 & 0.046 \\
\hline$C d h 13$ & 2.5 & 0.002 \\
\hline Cdh17 & 62.4 & 0.004 \\
\hline Cdh2 & 2.9 & 0.031 \\
\hline Cdk2 & -2.1 & 0.047 \\
\hline Cdk2ap2 & 1.9 & 0.001 \\
\hline Cdk5 & 2.3 & 0.001 \\
\hline Cdkn1a & 5.1 & 0.004 \\
\hline Cdkn2a & -71.7 & 0.035 \\
\hline Cdkn2aip, Carf & $\# N / A$ & $\# N / A$ \\
\hline$C d n f$ & 273.1 & 0.012 \\
\hline$C d v 3$ & 2.1 & 0.020 \\
\hline Cebpd & -1.8 & 0.029 \\
\hline Cers3 & 67.1 & 0.031 \\
\hline Cfap126 & -129.8 & 0.019 \\
\hline Cgnl1 & 7.2 & 0.001 \\
\hline Chchd10 & 5.9 & 0.041 \\
\hline Chi3/1 & -17.2 & 0.006 \\
\hline Chp1 & -2.0 & 0.036 \\
\hline Chpf2 & -1.7 & 0.016 \\
\hline
\end{tabular}




\begin{tabular}{|c|c|c|}
\hline Chrna4 & -12.6 & 0.022 \\
\hline Chrnb1 & 53.6 & 0.011 \\
\hline Chst11 & 11.2 & 0.039 \\
\hline Chst12 & -1.7 & 0.035 \\
\hline Chuk & -2.3 & 0.011 \\
\hline Cidea & -247.0 & 0.012 \\
\hline Cideb & -27.2 & 0.032 \\
\hline Cited1 & -39.0 & 0.035 \\
\hline Cited2 & 1.9 & 0.011 \\
\hline$c k b$ & 2.1 & 0.024 \\
\hline Cks2 & 1.8 & 0.037 \\
\hline Clca5 & 155.2 & 0.008 \\
\hline Clcn3 & -3.8 & 0.031 \\
\hline Cldn10 & -443.2 & 0.001 \\
\hline Cldn20 & -229.9 & 0.009 \\
\hline Cldnd1 & -2.0 & 0.000 \\
\hline Clip4 & 24.3 & 0.048 \\
\hline Clk1 & 2.7 & 0.001 \\
\hline$C \ln 3$ & 2.9 & 0.013 \\
\hline $\mathrm{Cln} 8$ & -2.8 & 0.011 \\
\hline Clock & 2.6 & 0.030 \\
\hline Clstn1 & 1.7 & 0.049 \\
\hline Clstn3 & 424.9 & 0.001 \\
\hline $\mathrm{Clu}$ & -1.9 & 0.018 \\
\hline Clvs1 & 1.9 & 0.042 \\
\hline Clvs2 & -76.4 & 0.041 \\
\hline Cmc1 & 2.1 & 0.006 \\
\hline Cmpk1 & -1.7 & 0.001 \\
\hline Cndp2 & -2.7 & 0.002 \\
\hline Cnep1r1 & -2.2 & 0.026 \\
\hline Cnih2 & -2.8 & 0.018 \\
\hline Cnn3 & -1.6 & 0.016 \\
\hline Cnot10 & 2.1 & 0.003 \\
\hline Cnp & -1.8 & 0.016 \\
\hline Cnp & -1.8 & 0.016 \\
\hline Cnrip1 & -1.7 & 0.032 \\
\hline Cntf & 25.6 & 0.000 \\
\hline Cntn1 & 115.3 & 0.009 \\
\hline Cntn6 & 361.2 & 0.003 \\
\hline Cntnap4 & 1391.6 & 0.001 \\
\hline Coa4 & 2.0 & 0.007 \\
\hline Coasy & 1.9 & 0.039 \\
\hline $\operatorname{Cog} 4$ & -1.5 & 0.021 \\
\hline $\operatorname{Cog} 6$ & -4.5 & 0.041 \\
\hline $\operatorname{Cog} 7$ & -2.2 & 0.017 \\
\hline Col26a1 & -3.6 & 0.017 \\
\hline
\end{tabular}




\begin{tabular}{|c|c|c|}
\hline Col4a3bp & 3.3 & 0.028 \\
\hline Col6a2 & 2.0 & 0.007 \\
\hline Commd4 & 1.9 & 0.003 \\
\hline Copg1 & -2.1 & 0.022 \\
\hline Coprs & 1.9 & 0.014 \\
\hline Cops4 & -2.1 & 0.001 \\
\hline Copz1 & -1.5 & 0.004 \\
\hline Coq10b & -2.1 & 0.028 \\
\hline Coro1a & -3.0 & 0.017 \\
\hline Coro2a & 144.1 & 0.004 \\
\hline Cot/1 & -1.7 & 0.021 \\
\hline Cox17 & 1.9 & 0.012 \\
\hline Cox20 & 1.7 & 0.029 \\
\hline Cox7b & 2.0 & 0.013 \\
\hline Cpeb1 & 276.3 & 0.015 \\
\hline Cpne9 & 33.9 & 0.026 \\
\hline$C p q$ & 1.6 & 0.032 \\
\hline Cpsf4 & -2.1 & 0.038 \\
\hline Cpt1c & 3.3 & 0.037 \\
\hline $\mathrm{Cr} 2$ & -201.2 & 0.009 \\
\hline Creb3/4 & 186.5 & 0.009 \\
\hline Crebbp & 1.7 & 0.049 \\
\hline Crip1 & 2.5 & 0.002 \\
\hline Crip2 & 1.7 & 0.009 \\
\hline Crlf3 & -4.8 & 0.003 \\
\hline Crls1 & -2.0 & 0.023 \\
\hline Crtac1 & 49.4 & 0.020 \\
\hline Cs & -1.8 & 0.010 \\
\hline Csf2ra & 3.7 & 0.000 \\
\hline Csnk1d & -1.6 & 0.003 \\
\hline Cspg 4 & 2.8 & 0.012 \\
\hline Csrp2 & -1.7 & 0.033 \\
\hline Cst3 & 2.9 & 0.000 \\
\hline Cstb & 1.8 & 0.021 \\
\hline Cstf1 & -2.7 & 0.000 \\
\hline Cstf2 & -2.8 & 0.045 \\
\hline Ctbs & 1.7 & 0.042 \\
\hline Ctdsp1 & 1.8 & 0.002 \\
\hline Ctdsp/2 & -2.4 & 0.024 \\
\hline Ctif & 33.6 & 0.034 \\
\hline Ctps1 & -2.5 & 0.000 \\
\hline Ctrb1 & 98.1 & 0.013 \\
\hline Ctsc & -2.7 & 0.008 \\
\hline Ctsd & 1.7 & 0.001 \\
\hline Ctse & -26.6 & 0.000 \\
\hline Ctsf & 1.7 & 0.021 \\
\hline
\end{tabular}




\begin{tabular}{|c|c|c|}
\hline Ctsw & -76.8 & 0.003 \\
\hline Ctsz & 3.6 & 0.004 \\
\hline Cuedc2 & 1.6 & 0.029 \\
\hline Cul1 & -2.9 & 0.000 \\
\hline Cul2 & -1.8 & 0.049 \\
\hline Cul3 & -1.6 & 0.018 \\
\hline$C x \mathrm{Cl} 1$ & 305.7 & 0.011 \\
\hline Cxcl10 & 136.2 & 0.021 \\
\hline Cxcl14 & -2.0 & 0.044 \\
\hline Cxcr2 & -43.8 & 0.035 \\
\hline Cxcr3 & 30.2 & 0.042 \\
\hline Cxcr6 & -226.8 & 0.025 \\
\hline$c y b 5 b$ & -1.6 & 0.034 \\
\hline$C y b a$ & 1.7 & 0.018 \\
\hline Cyfip2 & -7.9 & 0.002 \\
\hline Cyp27a1 & 9.7 & 0.038 \\
\hline Cyp27b1 & 163.4 & 0.019 \\
\hline Сyp2j10 & 220.6 & 0.001 \\
\hline Cyp2r1 & 45.8 & 0.022 \\
\hline Сур39а1 & 283.3 & 0.005 \\
\hline Сурза9 & 92.3 & 0.031 \\
\hline Cyp4b1 & 206.1 & 0.008 \\
\hline Cyp7b1 & -5.8 & 0.003 \\
\hline Cys/tr1 & -103.8 & 0.039 \\
\hline$D a b 2$ & -1.7 & 0.027 \\
\hline Dab2ip & 1.9 & 0.016 \\
\hline Dapk1 & 2.0 & 0.023 \\
\hline Dars & -2.4 & 0.013 \\
\hline Dbf4 & -3.8 & 0.039 \\
\hline$D b n 1$ & -1.5 & 0.045 \\
\hline Dcaf8 & -1.8 & 0.002 \\
\hline Dcdc2 & 93.5 & 0.031 \\
\hline Dcps & -2.6 & 0.008 \\
\hline$D c x r$ & 2.2 & 0.010 \\
\hline$D d x 46$ & 1.6 & 0.027 \\
\hline$D d x 50$ & -1.6 & 0.037 \\
\hline$D d \times 58$ & 3.8 & 0.022 \\
\hline$D d \times 59$ & 2.1 & 0.025 \\
\hline Dffa & 2.2 & 0.005 \\
\hline Dgkg & -15.8 & 0.028 \\
\hline$D g k i$ & 298.6 & 0.000 \\
\hline Dhcr24 & -35.7 & 0.002 \\
\hline Dhps & -2.1 & 0.002 \\
\hline Dhrs7c & 145.1 & 0.018 \\
\hline$D h \times 30$ & 2.1 & 0.006 \\
\hline$D h x 8$ & -2.6 & 0.013 \\
\hline
\end{tabular}




\begin{tabular}{|c|c|c|}
\hline$D k k l 1$ & -98.4 & 0.045 \\
\hline Dlgap4 & 2.1 & 0.002 \\
\hline DII1 & 7.2 & 0.031 \\
\hline Dnaja3 & -1.8 & 0.043 \\
\hline Dnajb13 & 263.7 & 0.002 \\
\hline Dnajb4 & -2.1 & 0.016 \\
\hline Dnajb6 & -2.1 & 0.015 \\
\hline Dnajc16 & -900.3 & 0.000 \\
\hline Dnase1/1 & 2.9 & 0.011 \\
\hline Dnase1/3 & -299.8 & 0.002 \\
\hline Dnase2 & 1.9 & 0.001 \\
\hline Dnase $2 b$ & 44.0 & 0.019 \\
\hline$D n l z$ & 1.9 & 0.021 \\
\hline Dnm3 & -3.3 & 0.043 \\
\hline Dock8 & -4.2 & 0.028 \\
\hline Dock9 & 2.9 & 0.034 \\
\hline Dpep1 & 29.8 & 0.039 \\
\hline Dpf1 & 92.0 & 0.001 \\
\hline Dph3 & 1.6 & 0.033 \\
\hline Dpp4 & -19.8 & 0.004 \\
\hline Dpp7 & 1.8 & 0.010 \\
\hline Dpyd & 84.5 & 0.003 \\
\hline Dpys/2 & 2.1 & 0.018 \\
\hline Dram2 & -1.9 & 0.026 \\
\hline Drg1 & -2.3 & 0.006 \\
\hline Dsc3 & 91.8 & 0.005 \\
\hline Dsg3 & 21.5 & 0.038 \\
\hline Duox1 & 3.7 & 0.011 \\
\hline Dusp10 & -2.6 & 0.048 \\
\hline Dusp3 & 1.9 & 0.005 \\
\hline Dusp4 & -33.4 & 0.038 \\
\hline Dvl1 & 2.1 & 0.012 \\
\hline Dym & -2.0 & 0.011 \\
\hline Dync1i2 & 1.5 & 0.047 \\
\hline Dyrk2 & 2.0 & 0.009 \\
\hline Eaf2 & -36.5 & 0.041 \\
\hline Edar & -74.6 & 0.045 \\
\hline$E d c 4$ & 2.1 & 0.003 \\
\hline Eef1a1 & -1.9 & 0.018 \\
\hline Eef1e1 & -2.1 & 0.003 \\
\hline Efemp1 & 5.1 & 0.037 \\
\hline Egf & 22.1 & 0.036 \\
\hline Egfl7 & 1.9 & 0.012 \\
\hline Egr2 & 653.0 & 0.001 \\
\hline Ehf & 187.0 & 0.020 \\
\hline Ehmt1 & -5.3 & 0.001 \\
\hline
\end{tabular}




\begin{tabular}{|c|c|c|}
\hline Ei24 & -2.2 & 0.000 \\
\hline Eif $2 b 1$ & -1.6 & 0.011 \\
\hline Eif $2 b 3$ & -2.5 & 0.003 \\
\hline Eif2s1 & -1.6 & 0.018 \\
\hline Eif $4 a 1$ & -1.5 & 0.002 \\
\hline Eif4e & -1.6 & 0.025 \\
\hline Elf1 & -2.8 & 0.016 \\
\hline Elf4 & -8.8 & 0.042 \\
\hline Elovi4 & -6.4 & 0.012 \\
\hline Elovi5 & -3.4 & 0.045 \\
\hline Emc4 & 1.7 & 0.002 \\
\hline Emd & 2.1 & 0.020 \\
\hline Emid1 & -2.9 & 0.000 \\
\hline Em/1 & -3.1 & 0.020 \\
\hline Enc1 & -3.1 & 0.010 \\
\hline Enoph1 & -2.0 & 0.028 \\
\hline Enpp1 & -2.5 & 0.018 \\
\hline Enpp2 & 3.1 & 0.020 \\
\hline Enpp6 & 130.7 & 0.001 \\
\hline Eogt & -23.6 & 0.015 \\
\hline Epc1 & 2.5 & 0.046 \\
\hline Epha1 & 233.9 & 0.003 \\
\hline Epha2 & 2.1 & 0.009 \\
\hline Erh & -1.6 & 0.001 \\
\hline Espn & 30.6 & 0.008 \\
\hline Esrp1 & 73.2 & 0.017 \\
\hline Esrp2 & 130.5 & 0.025 \\
\hline Etf1 & -1.5 & 0.030 \\
\hline Etv1 & 3.9 & 0.032 \\
\hline Evala & -1.8 & 0.027 \\
\hline Evpl & 203.0 & 0.010 \\
\hline Exoc6b & -3.4 & 0.003 \\
\hline Ezh1 & 3.7 & 0.009 \\
\hline F11r & -1.8 & 0.047 \\
\hline$F 12$ & -154.6 & 0.010 \\
\hline$F 2 r$ & -2.8 & 0.001 \\
\hline $\mathrm{Fa} 2 \mathrm{~h}$ & 25.3 & 0.037 \\
\hline Fabp5 & 2.7 & 0.015 \\
\hline Fah & 5.6 & 0.007 \\
\hline Fam118b & -2.1 & 0.045 \\
\hline Fam126a & -22.4 & 0.000 \\
\hline Fam126b & 4.2 & 0.035 \\
\hline Fam161a & -82.9 & 0.016 \\
\hline Fam172a & -2.0 & 0.025 \\
\hline Fam20c & 3.1 & 0.003 \\
\hline Fam26e & -15.4 & 0.041 \\
\hline
\end{tabular}




\begin{tabular}{|c|c|c|}
\hline Fam $26 f$ & 25.2 & 0.039 \\
\hline Fam46c & -2.4 & 0.032 \\
\hline Fam65a & 1.9 & 0.010 \\
\hline Fam96b & 1.7 & 0.010 \\
\hline Fam98c & 1.7 & 0.021 \\
\hline Fanca & 4.9 & 0.003 \\
\hline Farsb & -3.9 & 0.000 \\
\hline Fasn & 1.7 & 0.039 \\
\hline Fat1 & 2.3 & 0.036 \\
\hline $\mathrm{Fbx} / 4$ & -4.1 & 0.024 \\
\hline$F b x 15$ & -1.7 & 0.042 \\
\hline $\mathrm{FbxO2}$ & 204.6 & 0.026 \\
\hline Fbxo39 & 42.3 & 0.042 \\
\hline Fbxo44 & 214.6 & 0.016 \\
\hline Fbxo7 & -2.0 & 0.033 \\
\hline $\mathrm{Fcmr}$ & -5.2 & 0.020 \\
\hline Fcnb & -13.2 & 0.012 \\
\hline Fcrla & -6.4 & 0.049 \\
\hline$F d \times 1$ & 1.6 & 0.010 \\
\hline Fem1a & 1.8 & 0.003 \\
\hline Fermt1 & 5.8 & 0.036 \\
\hline $\mathrm{Fgd4}$ & 37.1 & 0.009 \\
\hline Fgfo & 57.2 & 0.022 \\
\hline Fgfbp1 & 1831.0 & 0.002 \\
\hline Fgfrl1 & 3.0 & 0.007 \\
\hline$F h / 2$ & -2.3 & 0.015 \\
\hline Fhod1 & 4.1 & 0.006 \\
\hline Fibp & 1.5 & 0.005 \\
\hline Flrt1 & 123.3 & 0.010 \\
\hline Flrt3 & -3.5 & 0.025 \\
\hline Flt3 & 27.8 & 0.023 \\
\hline Fmr1 & 2.1 & 0.006 \\
\hline Fndc3a & 3.3 & 0.002 \\
\hline Fnip1 & 2.7 & 0.008 \\
\hline Fnip2 & 23.1 & 0.007 \\
\hline Folh1 & -151.6 & 0.044 \\
\hline Folr2 & 3.5 & 0.010 \\
\hline Foxi3 & 45.4 & 0.037 \\
\hline Foxj1 & 109.3 & 0.021 \\
\hline Foxk1 & -3.7 & 0.040 \\
\hline Foxo3 & 2.2 & 0.015 \\
\hline Foxo4 & 6.1 & 0.024 \\
\hline Fpr1 & -282.3 & 0.003 \\
\hline Frmd3 & -143.3 & 0.027 \\
\hline Fscn3 & 531.0 & 0.006 \\
\hline Fsd1 & -242.3 & 0.011 \\
\hline
\end{tabular}




\begin{tabular}{|c|c|c|}
\hline Fto & -5.3 & 0.004 \\
\hline Fundc2 & 1.6 & 0.015 \\
\hline Furin & -2.0 & 0.000 \\
\hline Fut11 & -2.8 & 0.037 \\
\hline Fut7 & 215.2 & 0.003 \\
\hline Fut8 & -5.7 & 0.000 \\
\hline Fxyd1 & 1.8 & 0.038 \\
\hline Fxyd2 & 6.8 & 0.000 \\
\hline Fxyd3 & 5.4 & 0.034 \\
\hline G3bp1 & -1.9 & 0.002 \\
\hline G3bp2 & -4.0 & 0.024 \\
\hline Gabarapl1 & 1.8 & 0.003 \\
\hline Gabbr1 & 2.9 & 0.007 \\
\hline Gabbr2 & 533.6 & 0.004 \\
\hline Gabrd & 39.1 & 0.019 \\
\hline Gadd45g & 1.8 & 0.021 \\
\hline Gale & 2.5 & 0.017 \\
\hline Galm & 2.2 & 0.037 \\
\hline Galnt1 & -3.2 & 0.009 \\
\hline Galnt10 & -4.4 & 0.002 \\
\hline Galt & 1.6 & 0.050 \\
\hline Gatad $2 b$ & 2.9 & 0.019 \\
\hline Gatm & -2.7 & 0.009 \\
\hline Gba2 & 1.8 & 0.034 \\
\hline Gc & -122.8 & 0.017 \\
\hline Gcgr & 27.5 & 0.025 \\
\hline Gen1/1 & 1.8 & 0.040 \\
\hline Gfi1 & -52.5 & 0.017 \\
\hline Ggps1 & -2.7 & 0.014 \\
\hline Ghr & -2.0 & 0.005 \\
\hline Ghrl & 19.6 & 0.042 \\
\hline Gimap4 & 2.6 & 0.024 \\
\hline Gimap7 & -12.6 & 0.028 \\
\hline Gjb2 & 43.7 & 0.022 \\
\hline Gjb3 & 131.2 & 0.027 \\
\hline Gjc1 & -2.6 & 0.004 \\
\hline Gldn & 23.6 & 0.035 \\
\hline Glrb & -70.6 & 0.008 \\
\hline Glrx & -2.4 & 0.001 \\
\hline Gls & 1.8 & 0.018 \\
\hline Gls & 1.8 & 0.018 \\
\hline Gmnn & -2.6 & 0.009 \\
\hline Gmppa & 1.8 & 0.006 \\
\hline Gmppb & -2.8 & 0.000 \\
\hline Gmps & -1.7 & 0.029 \\
\hline Gnai3 & -1.5 & 0.012 \\
\hline
\end{tabular}




\begin{tabular}{|c|c|c|}
\hline Gnal & -1.7 & 0.018 \\
\hline Gnb1 & -1.6 & 0.014 \\
\hline Gngt2 & 2.3 & 0.013 \\
\hline Gn/2 & -2.5 & 0.005 \\
\hline Gn/3 & -1.5 & 0.019 \\
\hline Gnpda2 & -2.9 & 0.028 \\
\hline Gnpnat1 & -2.2 & 0.003 \\
\hline Golga1 & 3.8 & 0.003 \\
\hline Golga 7 & -1.9 & 0.026 \\
\hline Golt1b & -1.7 & 0.040 \\
\hline Gorasp2 & -1.5 & 0.043 \\
\hline Gpc1 & 1.7 & 0.030 \\
\hline Gpc3 & -10.5 & 0.000 \\
\hline Gpc4 & -1.7 & 0.043 \\
\hline Gpcpd1 & -2.6 & 0.002 \\
\hline Gpnmb & 3.1 & 0.033 \\
\hline Gpr174 & 58.6 & 0.010 \\
\hline Gprc5a & 65.2 & 0.021 \\
\hline Gpsm2 & -2.5 & 0.001 \\
\hline Grb10 & -1.8 & 0.029 \\
\hline Grik4 & 108.0 & 0.005 \\
\hline Grin2c & -84.4 & 0.049 \\
\hline Grm7 & 64.4 & 0.029 \\
\hline Grsf1 & -1.8 & 0.001 \\
\hline Gsn & 2.1 & 0.001 \\
\hline Gsr & -2.1 & 0.014 \\
\hline Gstk1 & 2.2 & 0.020 \\
\hline Gstm5 & -1.8 & 0.012 \\
\hline Gtpbp2 & 3.1 & 0.000 \\
\hline Haao & -139.1 & 0.014 \\
\hline Hadh & -2.5 & 0.044 \\
\hline Hat1 & -2.6 & 0.000 \\
\hline Haver2 & -327.5 & 0.027 \\
\hline Hbp1 & -2.1 & 0.002 \\
\hline$H c f c 1 r 1$ & 1.7 & 0.017 \\
\hline Hdac1 & -1.6 & 0.018 \\
\hline Hdac10 & 2.5 & 0.036 \\
\hline Hdac2 & -1.8 & 0.000 \\
\hline Hexa & 1.7 & 0.005 \\
\hline Hexim2 & -2.2 & 0.016 \\
\hline$H g f a c$ & 265.0 & 0.011 \\
\hline Hibadh & -2.2 & 0.013 \\
\hline Hif1a & -1.9 & 0.002 \\
\hline Higd1a & 1.6 & 0.031 \\
\hline Hint2 & 2.1 & 0.007 \\
\hline Hip1 & 2.0 & 0.014 \\
\hline
\end{tabular}




\begin{tabular}{|c|c|c|}
\hline Hipk2 & 3.7 & 0.031 \\
\hline Hist1h2bh & 2.1 & 0.012 \\
\hline Hist1h4m, Hist1h4b & $\# N / A$ & $\# \mathrm{~N} / \mathrm{A}$ \\
\hline Hivep1 & 3.1 & 0.019 \\
\hline Hivep3 & -4.9 & 0.028 \\
\hline $\mathrm{Hmgcl}$ & 2.1 & 0.010 \\
\hline Hmgn2 & -2.3 & 0.000 \\
\hline Hnrnpa2b1 & -1.8 & 0.017 \\
\hline Hnrnpdl & -1.6 & 0.020 \\
\hline Hnrnpf & -1.8 & 0.030 \\
\hline Hnrnph2 & -2.2 & 0.033 \\
\hline Hnrnpu & -1.5 & 0.002 \\
\hline Hoxb4 & -27.5 & 0.042 \\
\hline Hoxd4 & 6.8 & 0.031 \\
\hline Hoxd9 & 31.9 & 0.044 \\
\hline$H p$ & -3.3 & 0.036 \\
\hline Hpd & -110.3 & 0.027 \\
\hline Hras & 1.6 & 0.027 \\
\hline Hrh1 & -260.9 & 0.025 \\
\hline Hrh3 & -311.0 & 0.011 \\
\hline Hrk & 66.4 & 0.032 \\
\hline$H s d 17 b 14$ & 97.6 & 0.023 \\
\hline$H s d 17 b 8$ & 2.4 & 0.001 \\
\hline Hsdl2 & -1.9 & 0.045 \\
\hline Hsf2 & -2.2 & 0.028 \\
\hline Hspa1l & 128.5 & 0.022 \\
\hline Hspa5 & -1.7 & 0.002 \\
\hline Hspb1 & 4.6 & 0.000 \\
\hline Hsph1 & 2.1 & 0.013 \\
\hline$H \operatorname{tr} 1 b$ & -87.1 & 0.027 \\
\hline$H t r 2 b$ & 50.1 & 0.015 \\
\hline Htr7 & -107.7 & 0.027 \\
\hline Ica1 & 2.9 & 0.024 \\
\hline Icam4 & -322.7 & 0.009 \\
\hline Icam5 & 30.9 & 0.034 \\
\hline $1 d h 3 a$ & -1.9 & 0.012 \\
\hline Ifi27 & 1.9 & 0.013 \\
\hline$|f i 27| 2 b$ & 7.6 & 0.000 \\
\hline Ifngr2 & 1.7 & 0.014 \\
\hline Ift57 & -1.8 & 0.004 \\
\hline $\lg b p 1$ & 1.9 & 0.030 \\
\hline Igfbp6 & 54.1 & 0.000 \\
\hline Ikbip & -2.7 & 0.002 \\
\hline I/11 & 83.2 & 0.026 \\
\hline $1 / 16$ & -10.1 & 0.000 \\
\hline$\| 1 r \mid 1$ & -27.1 & 0.021 \\
\hline
\end{tabular}




\begin{tabular}{|c|c|c|}
\hline $1 / 3 r a$ & 2.5 & 0.020 \\
\hline IIf 2 & -1.8 & 0.017 \\
\hline IIf3 & 1.6 & 0.033 \\
\hline Impa1 & -2.2 & 0.001 \\
\hline Ina & -32.5 & 0.035 \\
\hline Ing4 & 1.6 & 0.007 \\
\hline Inha & 6.7 & 0.009 \\
\hline$I n h b a$ & 3.1 & 0.026 \\
\hline Ino80 & 2.5 & 0.039 \\
\hline Insc & -2.0 & 0.030 \\
\hline Insig2 & 1.9 & 0.029 \\
\hline Ins/3 & 143.6 & 0.017 \\
\hline Ip6k1 & -2.8 & 0.015 \\
\hline Ireb2 & -2.6 & 0.041 \\
\hline Irf3 & 1.9 & 0.011 \\
\hline Irgm & 4.3 & 0.012 \\
\hline $\operatorname{Irx} 2$ & 51.0 & 0.008 \\
\hline $\operatorname{lr} \times 6$ & 198.9 & 0.005 \\
\hline Isoc1 & -2.5 & 0.001 \\
\hline Itch & -3.9 & 0.027 \\
\hline Itga10 & 5.5 & 0.001 \\
\hline Itga11 & -2.9 & 0.009 \\
\hline $\operatorname{ltga} 4$ & -9.7 & 0.005 \\
\hline $\operatorname{ltg} a 8$ & 28.9 & 0.021 \\
\hline Itgae & 1.8 & 0.039 \\
\hline Itgb1bp2 & 66.9 & 0.017 \\
\hline $\operatorname{ltg} b 4$ & 3.1 & 0.009 \\
\hline $\operatorname{ltg} b 6$ & 142.4 & 0.013 \\
\hline Itm2a & -2.4 & 0.002 \\
\hline Itpka & 300.2 & 0.010 \\
\hline Itpkb & -8.6 & 0.023 \\
\hline Itsn 1 & -3.2 & 0.020 \\
\hline Jade3 & -536.5 & 0.002 \\
\hline Jmjd1c & 1.9 & 0.011 \\
\hline$J m j d 8$ & 1.7 & 0.006 \\
\hline Junb & 1.9 & 0.010 \\
\hline Kank1 & 3.9 & 0.017 \\
\hline Kars & -1.6 & 0.007 \\
\hline Kat7 & -1.8 & 0.049 \\
\hline Kcna1 & 149.8 & 0.018 \\
\hline Kcna2 & -182.6 & 0.045 \\
\hline Kcna3 & -92.5 & 0.043 \\
\hline Kcnab3 & 108.8 & 0.007 \\
\hline Kcng1 & -338.6 & 0.005 \\
\hline Kcnj12 & 122.8 & 0.039 \\
\hline Kcnj15 & 93.7 & 0.021 \\
\hline
\end{tabular}




\begin{tabular}{|c|c|c|}
\hline Kcnj9 & 86.0 & 0.016 \\
\hline Kcnmb4 & 3.1 & 0.001 \\
\hline Kcnq1 & 126.4 & 0.021 \\
\hline Kcnrg & -178.6 & 0.005 \\
\hline Kctd1 & 1.9 & 0.033 \\
\hline Kctd3 & -3.3 & 0.001 \\
\hline Kdelc2 & -1.7 & 0.049 \\
\hline$K d m 1 a$ & -1.7 & 0.003 \\
\hline$K d m 4 c$ & -11.3 & 0.000 \\
\hline$K d m 8$ & 2.0 & 0.038 \\
\hline Keap1 & 1.8 & 0.007 \\
\hline Kif19 & 72.2 & 0.037 \\
\hline Kif1c & 2.7 & 0.030 \\
\hline Kif26b & -4.6 & 0.030 \\
\hline Kif27 & -91.5 & 0.016 \\
\hline Kifc2 & 15.4 & 0.039 \\
\hline Kit & -33.8 & 0.013 \\
\hline KIf1 & -30.1 & 0.002 \\
\hline KIf13 & 1.9 & 0.004 \\
\hline KIf16 & -2.1 & 0.004 \\
\hline$K I f 3$ & 1.7 & 0.007 \\
\hline KIf4 & 6.5 & 0.000 \\
\hline KIf5 & 4.5 & 0.026 \\
\hline Klhdc10 & -3.3 & 0.040 \\
\hline Klhdc3 & -1.8 & 0.001 \\
\hline KIh/14 & -25.3 & 0.037 \\
\hline$K / h / 22$ & -1.6 & 0.034 \\
\hline$K / h / 40$ & 209.8 & 0.026 \\
\hline$K I h / 41$ & 145.5 & 0.015 \\
\hline Klh/8 & 2.1 & 0.034 \\
\hline Klh/9 & -1.7 & 0.011 \\
\hline KIk4 & -2388.5 & 0.004 \\
\hline Klk8 & 115.4 & 0.021 \\
\hline Klk8 & 115.4 & 0.021 \\
\hline KIrk1 & -114.8 & 0.025 \\
\hline$K m t 2 e$ & 1.8 & 0.002 \\
\hline Kpna1 & -2.5 & 0.047 \\
\hline Kpnb1 & -2.4 & 0.010 \\
\hline Krt10 & 2.4 & 0.034 \\
\hline Krt15 & 366.7 & 0.013 \\
\hline Krt17 & 21.1 & 0.033 \\
\hline Krt80 & 611.8 & 0.008 \\
\hline Ksr1 & -6.0 & 0.011 \\
\hline$L 3 m b t / 2$ & 2.0 & 0.035 \\
\hline Lamtor2 & 1.7 & 0.011 \\
\hline Lamtor4 & 1.7 & 0.009 \\
\hline
\end{tabular}




\begin{tabular}{|c|c|c|}
\hline Lancl2 & -4.1 & 0.036 \\
\hline Laptm4b & -2.0 & 0.000 \\
\hline Larp6 & 3.8 & 0.002 \\
\hline $\mathrm{Lbr}$ & -3.2 & 0.032 \\
\hline$L b r$ & -3.2 & 0.032 \\
\hline Ldah & -3.1 & 0.003 \\
\hline$L d b 2$ & 2.5 & 0.010 \\
\hline Leprot & 1.7 & 0.004 \\
\hline Lgals3 & 5.3 & 0.000 \\
\hline Lgals7 & 165.8 & 0.002 \\
\hline Lgr5 & 390.4 & 0.014 \\
\hline Lime1 & 13.5 & 0.004 \\
\hline Lims1 & -2.3 & 0.001 \\
\hline Liph & 105.6 & 0.024 \\
\hline Litaf & 1.8 & 0.003 \\
\hline Lix1l & 2.2 & 0.006 \\
\hline Llgl1 & -2.0 & 0.003 \\
\hline Lmbr1I & 2.7 & 0.041 \\
\hline $\operatorname{Lmf2}$ & 2.0 & 0.000 \\
\hline Lmna & 1.5 & 0.033 \\
\hline Lmnb1 & -3.1 & 0.017 \\
\hline LOC100302465 & -164.2 & 0.023 \\
\hline Lpar6 & -1.7 & 0.050 \\
\hline$L p p$ & 2.3 & 0.030 \\
\hline Lrfn 4 & 1.8 & 0.030 \\
\hline Lrrc1 & -4.4 & 0.044 \\
\hline $\operatorname{Lrrc29}$ & 255.4 & 0.001 \\
\hline Lrrc46 & 802.5 & 0.001 \\
\hline$L r r c 4 b$ & 2.6 & 0.031 \\
\hline Lrrc59 & -1.6 & 0.048 \\
\hline Lrrn3 & -19.7 & 0.036 \\
\hline LRRTM1 & -28.4 & 0.007 \\
\hline Lsm14a & -1.5 & 0.031 \\
\hline Lsm8 & 1.6 & 0.025 \\
\hline Lss & -10.1 & 0.001 \\
\hline Lst1 & -5.0 & 0.010 \\
\hline Lta4h & -1.8 & 0.030 \\
\hline Ltbp1 & 2.8 & 0.001 \\
\hline Ltv1 & -1.9 & 0.012 \\
\hline Luc7l & 2.2 & 0.001 \\
\hline Ly6d & 840.4 & 0.000 \\
\hline Ly6g6f & -78.6 & 0.028 \\
\hline Lynx1 & 835.0 & 0.020 \\
\hline Lypd3 & 12.4 & 0.022 \\
\hline Lypla1 & -2.1 & 0.003 \\
\hline Magt1 & -3.6 & 0.000 \\
\hline
\end{tabular}




\begin{tabular}{|c|c|c|}
\hline Mal2 & 113.9 & 0.010 \\
\hline Mamdc4 & 73.4 & 0.016 \\
\hline Man1a1 & -3.6 & 0.027 \\
\hline Maoa & -2.4 & 0.033 \\
\hline Map2 & -25.9 & 0.033 \\
\hline Map2 & -25.9 & 0.033 \\
\hline Map3k11 & 2.1 & 0.040 \\
\hline Map4k1 & -3.2 & 0.012 \\
\hline Map4k4 & 2.4 & 0.022 \\
\hline Mapk11 & 139.4 & 0.017 \\
\hline Mapk13 & 64.3 & 0.007 \\
\hline Mapre1 & -1.6 & 0.009 \\
\hline Mapt & 20.7 & 0.042 \\
\hline Marc1 & 4.3 & 0.036 \\
\hline March2 & 2.3 & 0.000 \\
\hline March3 & -4.1 & 0.015 \\
\hline March5 & -2.2 & 0.010 \\
\hline March7 & -7.2 & 0.000 \\
\hline Matk & 4.5 & 0.026 \\
\hline Mbip & -2.5 & 0.020 \\
\hline$M c c$ & 21.3 & 0.027 \\
\hline Mccc1 & -2.5 & 0.049 \\
\hline Mccc2 & -1.9 & 0.048 \\
\hline$M c f d 2$ & -1.9 & 0.001 \\
\hline Mcl1 & -1.6 & 0.026 \\
\hline Mcm10 & -43.8 & 0.000 \\
\hline Mcm2 & -2.8 & 0.005 \\
\hline Mcm4 & -2.1 & 0.010 \\
\hline Mcm6 & -2.6 & 0.017 \\
\hline Mcoln3 & 75.4 & 0.014 \\
\hline Mcpt2 & -421.7 & 0.003 \\
\hline Mdfic & 1.7 & 0.043 \\
\hline$M d k$ & -1.7 & 0.031 \\
\hline Me3 & 131.8 & 0.003 \\
\hline Mea1 & 1.6 & 0.014 \\
\hline Med13 & 2.3 & 0.006 \\
\hline Med15 & 1.7 & 0.003 \\
\hline Med19 & 1.7 & 0.029 \\
\hline Med20 & -2.0 & 0.009 \\
\hline Med31 & 1.8 & 0.002 \\
\hline$M e f 2 b$ & -53.1 & 0.047 \\
\hline Mei4 & -137.5 & 0.028 \\
\hline Mest & -6.6 & 0.000 \\
\hline Mett/23 & 1.8 & 0.030 \\
\hline Mett/4 & -12.7 & 0.025 \\
\hline Mfsd12 & -26.6 & 0.014 \\
\hline
\end{tabular}




\begin{tabular}{|c|c|c|}
\hline Mgarp & 341.5 & 0.005 \\
\hline Mgp & 2.2 & 0.034 \\
\hline Mgrn1 & -2.8 & 0.006 \\
\hline Mid1ip1 & 2.3 & 0.023 \\
\hline Mina & -3.0 & 0.001 \\
\hline Mios & -2.9 & 0.001 \\
\hline Mis12 & -2.5 & 0.022 \\
\hline Mknk2 & -1.6 & 0.020 \\
\hline Mlana & 35.3 & 0.001 \\
\hline Mlph & 76.0 & 0.020 \\
\hline Mmgt1 & -2.8 & 0.049 \\
\hline Mmp23 & -1.8 & 0.038 \\
\hline Mmp24 & 2.2 & 0.019 \\
\hline Mmp3 & 107.3 & 0.012 \\
\hline Mok & 4.7 & 0.036 \\
\hline Morc1 & -58.8 & 0.038 \\
\hline Morf4l2 & -1.7 & 0.001 \\
\hline Mospd4 & 146.2 & 0.013 \\
\hline Mpc2 & 1.9 & 0.008 \\
\hline Mpg & 1.6 & 0.040 \\
\hline Mpp6 & -1.9 & 0.015 \\
\hline Mprip & -1.5 & 0.015 \\
\hline Mpv17/2 & 1.7 & 0.022 \\
\hline$M p z / 2$ & 21.1 & 0.023 \\
\hline Mrc1 & 1.8 & 0.031 \\
\hline Mri1 & 2.8 & 0.004 \\
\hline Mrpl14 & 1.6 & 0.022 \\
\hline Mrpl32 & 1.7 & 0.009 \\
\hline Mrpl54 & 1.8 & 0.041 \\
\hline mrp/9 & 2.1 & 0.001 \\
\hline Mrps2 & -2.0 & 0.026 \\
\hline Mrps22 & 1.8 & 0.049 \\
\hline Mrps27 & -2.2 & 0.049 \\
\hline Mrps30 & -1.8 & 0.025 \\
\hline Ms4a1 & -12.6 & 0.014 \\
\hline Ms4a2 & -40.1 & 0.014 \\
\hline Ms/1 & 1.7 & 0.006 \\
\hline Mst1r & 41.7 & 0.049 \\
\hline Msto1 & 2.2 & 0.047 \\
\hline Mt1a & 7.5 & 0.000 \\
\hline$M t 3$ & 60.7 & 0.000 \\
\hline Mt4 & 1334.1 & 0.003 \\
\hline Mta2 & -1.7 & 0.015 \\
\hline Mterfd1 & -2.2 & 0.000 \\
\hline$M t f 2$ & -1.6 & 0.041 \\
\hline Mtmr2 & -1.8 & 0.048 \\
\hline
\end{tabular}




\begin{tabular}{|c|c|c|}
\hline Mtmr7 & -52.9 & 0.020 \\
\hline Mto1 & 3.2 & 0.037 \\
\hline Mtrr & 2.7 & 0.017 \\
\hline Muc1 & 233.8 & 0.004 \\
\hline Muc20 & -445.1 & 0.007 \\
\hline$M v b 12 a$ & 1.9 & 0.002 \\
\hline$M \times 2$ & 229.4 & 0.010 \\
\hline Mybl1 & 80.7 & 0.010 \\
\hline Myc & -2.0 & 0.001 \\
\hline Mycbp2 & 2.1 & 0.028 \\
\hline Myh10 & -1.6 & 0.043 \\
\hline Myl1 & 1233.0 & 0.003 \\
\hline Mylpf & 6.6 & 0.043 \\
\hline Myold & 3.0 & 0.001 \\
\hline Myole & 2.6 & 0.043 \\
\hline Myo7a & 30.1 & 0.045 \\
\hline Myo9a & 3.3 & 0.006 \\
\hline Муос & 155.0 & 0.011 \\
\hline Myof & 2.5 & 0.019 \\
\hline Myom 2 & 706.7 & 0.004 \\
\hline$M z b 1$ & -17.6 & 0.021 \\
\hline$N 4 b p 212$ & 1.7 & 0.008 \\
\hline Nadk2 & -3.7 & 0.010 \\
\hline Nags & 82.2 & 0.006 \\
\hline Ncaph2 & -2.0 & 0.012 \\
\hline Ncbp1 & -1.9 & 0.003 \\
\hline Ncf2 & -117.9 & 0.014 \\
\hline Ncoa5 & -2.6 & 0.000 \\
\hline Ndel1 & -1.6 & 0.033 \\
\hline Ndfip2 & -1.9 & 0.004 \\
\hline Ndufa10 & -1.7 & 0.004 \\
\hline Ndufaf1 & -9.7 & 0.006 \\
\hline Ndufs5 & 2.3 & 0.003 \\
\hline Nek6 & -4.0 & 0.000 \\
\hline Neto2 & -5.7 & 0.046 \\
\hline Neu3 & 25.5 & 0.012 \\
\hline Nfat5 & 2.1 & 0.047 \\
\hline Nfatc1 & 1.7 & 0.017 \\
\hline$N f i l 3$ & -2.3 & 0.019 \\
\hline Nfkbia & 1.5 & 0.002 \\
\hline Nfkbiz & 6.4 & 0.011 \\
\hline$N f \times 1$ & -2.6 & 0.001 \\
\hline$N g p$ & -19.0 & 0.011 \\
\hline $\mathrm{Nin}$ & 6.7 & 0.003 \\
\hline$N k \times 2-3$ & 67.5 & 0.028 \\
\hline$N k x 6-3$ & 94.9 & 0.009 \\
\hline
\end{tabular}




\begin{tabular}{|c|c|c|}
\hline $\mathrm{Nmbr}$ & 49.8 & 0.044 \\
\hline Nmnat2 & 70.0 & 0.026 \\
\hline Nmur1 & -108.6 & 0.030 \\
\hline Nnat & 4.5 & 0.000 \\
\hline Nnt & -1.5 & 0.017 \\
\hline Nob1 & 1.7 & 0.011 \\
\hline Noc2l & -3.1 & 0.001 \\
\hline Nod2 & 23.3 & 0.037 \\
\hline Nol10 & -2.4 & 0.019 \\
\hline Nop56 & -1.7 & 0.033 \\
\hline Nop58 & -1.5 & 0.028 \\
\hline Nos1 & 41.0 & 0.035 \\
\hline Nos2 & 63.9 & 0.025 \\
\hline Notch1 & 2.1 & 0.011 \\
\hline Notch4 & 2.1 & 0.018 \\
\hline Npas2 & 5.5 & 0.010 \\
\hline$N p c 1$ & 3.0 & 0.003 \\
\hline Nphs1 & 67.9 & 0.027 \\
\hline Npr3 & -423.3 & 0.014 \\
\hline Nptn & 1.6 & 0.005 \\
\hline Npy4r & -131.4 & 0.035 \\
\hline Npy5r & 64.0 & 0.040 \\
\hline $\mathrm{NrOb2}$ & 416.4 & 0.002 \\
\hline Nr1h2 & 1.7 & 0.002 \\
\hline$N r 2 c 1$ & -2.3 & 0.017 \\
\hline Nr4a1 & 2.4 & 0.047 \\
\hline Nras & -2.2 & 0.047 \\
\hline Nrg1 & 103.2 & 0.011 \\
\hline Nrg1 & 103.2 & 0.011 \\
\hline $\mathrm{Nrg} 2$ & -8.5 & 0.043 \\
\hline Nrp2 & -2.2 & 0.042 \\
\hline Nrxn1 & -5.6 & 0.039 \\
\hline Nsg1 & -1.9 & 0.022 \\
\hline Nsmce $4 a$ & -1.7 & 0.014 \\
\hline Nsun2 & -2.3 & 0.001 \\
\hline$N t 5 c 1 b$ & -70.8 & 0.048 \\
\hline Ntmt1 & 1.6 & 0.005 \\
\hline Ntn3 & -3.0 & 0.048 \\
\hline Nuak2 & 14.4 & 0.027 \\
\hline Nudt17 & 342.1 & 0.005 \\
\hline Nufip1 & -2.1 & 0.013 \\
\hline Numa1 & 2.0 & 0.003 \\
\hline Nup35 & -1.8 & 0.034 \\
\hline Nup62 & -2.1 & 0.003 \\
\hline Nup93 & -1.9 & 0.012 \\
\hline Nupl1 & -5.9 & 0.004 \\
\hline
\end{tabular}




\begin{tabular}{|c|c|c|}
\hline Nus1 & -1.8 & 0.010 \\
\hline Oas3 & 81.3 & 0.017 \\
\hline Oat & -1.6 & 0.001 \\
\hline Ogdhl & 13.2 & 0.014 \\
\hline Ogdhl,Ogdh & $\# N / A$ & $\# N / A$ \\
\hline Ogfr & 1.7 & 0.004 \\
\hline Olfm4 & -16.4 & 0.045 \\
\hline Ormdl2 & 2.1 & 0.001 \\
\hline Ormdl3 & -1.9 & 0.044 \\
\hline Ovol1 & 120.7 & 0.009 \\
\hline P2rx3 & -14.2 & 0.038 \\
\hline P2ry2 & 2.8 & 0.047 \\
\hline P4ha3 & -3.4 & 0.004 \\
\hline Pafah1b2 & -3.0 & 0.000 \\
\hline Pafah2 & -104.0 & 0.004 \\
\hline Pak1 & -3.7 & 0.001 \\
\hline Pak3 & -4.6 & 0.039 \\
\hline Palmd & 3.5 & 0.006 \\
\hline Palmd & 3.5 & 0.006 \\
\hline Pam16 & 1.9 & 0.024 \\
\hline Pam16 & 1.9 & 0.024 \\
\hline Pard3b & 2.4 & 0.024 \\
\hline Pard6g & -2.8 & 0.000 \\
\hline Parl & -1.6 & 0.015 \\
\hline Parvg & -41.7 & 0.009 \\
\hline Pax8 & 724.6 & 0.001 \\
\hline Paxip1 & -2.0 & 0.039 \\
\hline$P c$ & -2.9 & 0.018 \\
\hline$P c$ & -2.9 & 0.018 \\
\hline$P c c b$ & -1.8 & 0.006 \\
\hline Pcdh18 & -2.2 & 0.033 \\
\hline Pcdh9 & -11.9 & 0.001 \\
\hline Pcdhga8 & 55.3 & 0.029 \\
\hline Pck2 & 1.9 & 0.005 \\
\hline Pcmtd1 & 1.6 & 0.025 \\
\hline Pcmtd2 & 1.6 & 0.044 \\
\hline Pcsk1 & 1275.4 & 0.000 \\
\hline Pcsk1 & 1275.4 & 0.000 \\
\hline Pde10a & 411.1 & 0.001 \\
\hline Pde1b & -291.6 & 0.018 \\
\hline Pde4dip & -2.1 & 0.006 \\
\hline Pdia4 & -1.9 & 0.001 \\
\hline Pdia6 & -2.2 & 0.000 \\
\hline Pdk1 & -1.8 & 0.015 \\
\hline$P d k 1$ & -1.8 & 0.015 \\
\hline Pdlim2 & 2.2 & 0.012 \\
\hline
\end{tabular}




\begin{tabular}{|c|c|c|}
\hline Pdlim5 & -3.2 & 0.002 \\
\hline$P d p r$ & -235.7 & 0.002 \\
\hline$P d x p$ & -3.2 & 0.000 \\
\hline$P d z d 2$ & 4.2 & 0.014 \\
\hline$P d z d 7$ & 175.7 & 0.025 \\
\hline Pecam1 & 1.9 & 0.014 \\
\hline Peg3 & -2.0 & 0.029 \\
\hline Peg3 & -2.0 & 0.029 \\
\hline Peli1 & -2.4 & 0.027 \\
\hline Penk & -2.4 & 0.020 \\
\hline Per3 & -3.8 & 0.034 \\
\hline Pet100 & 1.6 & 0.037 \\
\hline Pex11b & -2.5 & 0.028 \\
\hline Pex13 & -1.7 & 0.022 \\
\hline Pex16 & 2.3 & 0.001 \\
\hline Pex26 & 4.3 & 0.005 \\
\hline Pex6 & 2.0 & 0.042 \\
\hline Pex7 & -8.9 & 0.001 \\
\hline Pfdn6 & 2.0 & 0.049 \\
\hline Pgam2 & -21.0 & 0.036 \\
\hline Pgbd5 & -410.6 & 0.008 \\
\hline Pggt1b & -3.7 & 0.014 \\
\hline Pgp & 1.5 & 0.023 \\
\hline Phb2 & -1.5 & 0.005 \\
\hline Phkg1 & 134.3 & 0.016 \\
\hline Phkg2 & 1.9 & 0.004 \\
\hline Pias2 & -1.8 & 0.040 \\
\hline Picalm & -2.1 & 0.030 \\
\hline Pid1 & -3.4 & 0.013 \\
\hline Pigl & 6.8 & 0.002 \\
\hline Pigm & -6.7 & 0.016 \\
\hline Pign & -10.2 & 0.023 \\
\hline Pigp & 2.8 & 0.000 \\
\hline Pih1d2 & 3.2 & 0.019 \\
\hline$P i k 3 c 2 a$ & 2.9 & 0.008 \\
\hline$P i k 3 c 2 g$ & 33.6 & 0.042 \\
\hline Pik3cb & 27.4 & 0.011 \\
\hline Pik3r1 & 4.1 & 0.006 \\
\hline Pim3 & 2.5 & 0.000 \\
\hline Pirt & -175.4 & 0.015 \\
\hline$P k d 1$ & 2.0 & 0.015 \\
\hline$P k d c c$ & -2.0 & 0.006 \\
\hline Pkig & 1.7 & 0.014 \\
\hline Pknox2 & -19.6 & 0.023 \\
\hline Pla2g12a & 2.6 & 0.027 \\
\hline Pla2g5 & 7.9 & 0.000 \\
\hline
\end{tabular}




\begin{tabular}{|c|c|c|}
\hline Pla $2 g 7$ & 4.0 & 0.046 \\
\hline Plag1 & 198.1 & 0.009 \\
\hline Plcb2 & 115.8 & 0.001 \\
\hline Plcg1 & 1.8 & 0.037 \\
\hline Plec & 1.8 & 0.017 \\
\hline Plekha3 & -1.5 & 0.036 \\
\hline Plekha4 & 6.0 & 0.034 \\
\hline Plekha8 & 2.4 & 0.045 \\
\hline Plekhf1 & 1.9 & 0.006 \\
\hline Plekhn1 & 867.1 & 0.001 \\
\hline Plet1 & 549.9 & 0.017 \\
\hline $\mathrm{Plg}$ & 411.9 & 0.006 \\
\hline Plin1 & 80.0 & 0.021 \\
\hline Plod3 & 1.6 & 0.042 \\
\hline Pnisr & 2.3 & 0.003 \\
\hline Pnpla7 & 4.0 & 0.000 \\
\hline Pof1b & 216.9 & 0.003 \\
\hline Pold4 & 1.6 & 0.026 \\
\hline Poli & 21.1 & 0.020 \\
\hline Polr1a,Rpa1 & $\# N / A$ & $\# N / A$ \\
\hline Polr2k & 2.5 & 0.004 \\
\hline Polr2m & -1.9 & 0.015 \\
\hline Polr3e & -2.6 & 0.002 \\
\hline Pon2 & -2.0 & 0.005 \\
\hline Pop5 & 2.3 & 0.001 \\
\hline Popdc3 & -332.3 & 0.012 \\
\hline Porcn & 1.9 & 0.024 \\
\hline Pot1 & -2.8 & 0.013 \\
\hline Pou2af1 & -21.5 & 0.030 \\
\hline Pou3f3 & 39.6 & 0.035 \\
\hline Ppa2 & -2.0 & 0.004 \\
\hline Ppef2 & 54.9 & 0.024 \\
\hline Ppfia3 & -63.7 & 0.003 \\
\hline Ppfibp2 & 2.3 & 0.002 \\
\hline Ppm1a & -1.7 & 0.013 \\
\hline Ppm1g & -1.6 & 0.007 \\
\hline Ppp1r10 & 1.5 & 0.040 \\
\hline Ppp1r14b & 1.6 & 0.032 \\
\hline Ppp1r7 & -1.7 & 0.034 \\
\hline Ppp1r8 & 2.2 & 0.013 \\
\hline Ppp1r9a & 52.8 & 0.044 \\
\hline Ppp2ca & -1.6 & 0.039 \\
\hline Ppp2r1b & -2.6 & 0.024 \\
\hline Ppp2r5c & -1.7 & 0.011 \\
\hline Ppp3cc & -2.4 & 0.003 \\
\hline Ppp3r1 & -2.3 & 0.002 \\
\hline
\end{tabular}




\begin{tabular}{|c|c|c|}
\hline Prdm2 & 2.4 & 0.048 \\
\hline $\operatorname{Prd} x 3$ & -1.6 & 0.015 \\
\hline Prickle2 & -2.3 & 0.032 \\
\hline Prkar1a & -1.8 & 0.002 \\
\hline Prkcd & -2.4 & 0.001 \\
\hline Prkcq & -26.1 & 0.034 \\
\hline Prkcsh & 1.6 & 0.003 \\
\hline Prkx & -3.5 & 0.007 \\
\hline Prmt3 & -3.0 & 0.003 \\
\hline Proc & 124.7 & 0.029 \\
\hline Prokr2 & -167.6 & 0.000 \\
\hline Prox2 & 94.0 & 0.031 \\
\hline Prpf18 & 2.0 & 0.017 \\
\hline Prpf38b & 1.6 & 0.033 \\
\hline Prpf40a & -1.5 & 0.005 \\
\hline Prpf40b & 2.0 & 0.042 \\
\hline Prps1 & -2.2 & 0.006 \\
\hline Prr13 & 1.8 & 0.005 \\
\hline Prss12 & -5.3 & 0.000 \\
\hline Prss30 & -129.5 & 0.037 \\
\hline Prss8 & 301.4 & 0.003 \\
\hline Psat1 & -4.1 & 0.017 \\
\hline Psmb10 & 1.7 & 0.028 \\
\hline Psmd3 & -1.6 & 0.016 \\
\hline Pstpip1 & 4.7 & 0.010 \\
\hline Pstpip2 & -18.3 & 0.025 \\
\hline Ptbp2 & -4.3 & 0.024 \\
\hline Ptch2 & 29.1 & 0.050 \\
\hline Ptdss1 & -1.9 & 0.001 \\
\hline Ptdss2 & -2.0 & 0.003 \\
\hline Ptger2 & 113.7 & 0.012 \\
\hline Ptges & -2.5 & 0.006 \\
\hline Ptges3/1 & -12.4 & 0.008 \\
\hline Ptgis & 4.1 & 0.000 \\
\hline Ptgs1 & -3.8 & 0.008 \\
\hline Ptgs2 & -225.2 & 0.012 \\
\hline Ptk2 & -1.6 & 0.009 \\
\hline Ptk7 & -1.5 & 0.046 \\
\hline Ptp4a1 & -2.9 & 0.023 \\
\hline Ptpn12 & 2.1 & 0.018 \\
\hline Ptpn2 & -1.8 & 0.027 \\
\hline Ptpre & 3.2 & 0.004 \\
\hline Ptprn & 183.4 & 0.013 \\
\hline Ptprz1 & 2.3 & 0.017 \\
\hline Purb & 1.5 & 0.046 \\
\hline Pvalb & 33.6 & 0.042 \\
\hline
\end{tabular}




\begin{tabular}{|c|c|c|}
\hline Pwp2 & -2.8 & 0.029 \\
\hline Pycr2 & 1.6 & 0.004 \\
\hline Pycrl & -1.6 & 0.034 \\
\hline Qdpr & -1.7 & 0.039 \\
\hline Rab18 & -1.6 & 0.024 \\
\hline$R a b 1 b$ & -2.3 & 0.027 \\
\hline Rab31 & 1.6 & 0.033 \\
\hline Rab39a & 63.9 & 0.021 \\
\hline$R a b 3 b$ & 123.6 & 0.023 \\
\hline$R a b 5 a$ & -3.0 & 0.022 \\
\hline$R a b 6 b$ & -5.4 & 0.045 \\
\hline$R a b 8 a$ & -1.6 & 0.000 \\
\hline Rabgap1l & 3.5 & 0.037 \\
\hline Rabggta & -2.0 & 0.029 \\
\hline Rabggtb & 1.8 & 0.048 \\
\hline Racgap1 & -6.0 & 0.004 \\
\hline Rag1 & -28.2 & 0.044 \\
\hline $\operatorname{Rag} 2$ & -559.7 & 0.006 \\
\hline Ralbp1 & 1.8 & 0.026 \\
\hline Raly & -1.6 & 0.002 \\
\hline Ramp1 & 2.3 & 0.000 \\
\hline Rap1b & -2.0 & 0.031 \\
\hline Rapgef6 & -3.3 & 0.025 \\
\hline Rarb & -6.7 & 0.006 \\
\hline Rasal1 & 681.4 & 0.002 \\
\hline Raver1 & -1.8 & 0.008 \\
\hline Rbbp7 & -1.9 & 0.002 \\
\hline Rbbp9 & -2.4 & 0.023 \\
\hline Rbp2 & 106.2 & 0.035 \\
\hline Rbp2 & 106.2 & 0.035 \\
\hline Rbsn & -2.1 & 0.036 \\
\hline Rcbtb1 & -2.9 & 0.020 \\
\hline Rcl1 & -2.0 & 0.038 \\
\hline Rcl1,Clns1a & $\# N / A$ & $\# N / A$ \\
\hline Rcor1 & 1.7 & 0.011 \\
\hline Rdh12 & 227.6 & 0.003 \\
\hline$R d m 1$ & 1.9 & 0.042 \\
\hline Reep2 & 46.7 & 0.012 \\
\hline Reep4 & 2.0 & 0.025 \\
\hline Reep5 & 1.5 & 0.006 \\
\hline Reln & -14.2 & 0.048 \\
\hline Rem2 & 33.0 & 0.040 \\
\hline Rev1 & -2.0 & 0.012 \\
\hline$R f w d 2$ & -1.8 & 0.001 \\
\hline$R f x 6$ & 39.6 & 0.039 \\
\hline RGD1309730 & 1.8 & 0.023 \\
\hline
\end{tabular}




\begin{tabular}{|c|c|c|}
\hline RGD1311892 & 64.8 & 0.030 \\
\hline RGD1560436 & -96.7 & 0.031 \\
\hline RGD1561102 & -168.7 & 0.025 \\
\hline RGD1564379 & -1.6 & 0.009 \\
\hline Rgs10 & 2.0 & 0.009 \\
\hline $\operatorname{Rgs} 18$ & -43.7 & 0.000 \\
\hline Rgs2 & -2.5 & 0.010 \\
\hline Rgs3 & 2.0 & 0.003 \\
\hline Rgs7 & -146.2 & 0.041 \\
\hline Rhd & -19.7 & 0.005 \\
\hline Rhoh & -7.6 & 0.025 \\
\hline Rhot2 & 2.7 & 0.006 \\
\hline Rims2 & -197.4 & 0.003 \\
\hline Ring1 & 1.6 & 0.022 \\
\hline Riok2 & -1.9 & 0.039 \\
\hline Rita1 & 2.6 & 0.003 \\
\hline Rnaseh1 & 2.0 & 0.040 \\
\hline Rnaseh2a & 2.2 & 0.002 \\
\hline Rnaseh $2 b$ & -2.0 & 0.010 \\
\hline Rnf111 & 1.8 & 0.040 \\
\hline Rnf114 & -1.6 & 0.002 \\
\hline Rnf11/1 & -2.7 & 0.006 \\
\hline Rnf123 & -2.1 & 0.009 \\
\hline Rnf13 & -3.1 & 0.049 \\
\hline Rnf2 & -2.0 & 0.002 \\
\hline Rnf215 & 1.7 & 0.041 \\
\hline Rnf39 & 148.1 & 0.010 \\
\hline Rnf4 & -5.5 & 0.000 \\
\hline Rnmt & -1.9 & 0.009 \\
\hline Robo1 & -4.2 & 0.023 \\
\hline Rogdi & -1.7 & 0.047 \\
\hline Rpa1 & -7.4 & 0.002 \\
\hline Rpa1 & -7.4 & 0.002 \\
\hline Rpain & 2.1 & 0.014 \\
\hline Rpf2 & -1.8 & 0.049 \\
\hline Rpgrip1l & 3.4 & 0.023 \\
\hline Rpl37a & -16.5 & 0.043 \\
\hline Rpn 1 & -1.5 & 0.001 \\
\hline Rpp21 & 1.8 & 0.005 \\
\hline Rpp25 & -64.6 & 0.001 \\
\hline Rps17 & 2.7 & 0.010 \\
\hline Rps6ka3 & -3.8 & 0.000 \\
\hline Rps6kb1 & -1.7 & 0.046 \\
\hline Rragc & -1.7 & 0.009 \\
\hline Rras & 1.6 & 0.025 \\
\hline Rreb1 & 2.3 & 0.045 \\
\hline
\end{tabular}




\begin{tabular}{|c|c|c|}
\hline Rrn3 & -3.0 & 0.046 \\
\hline Rrp8 & -3.7 & 0.010 \\
\hline Rsad2 & -13.6 & 0.007 \\
\hline$R s / 24 d 1$ & -2.0 & 0.009 \\
\hline Rtkn2 & -33.4 & 0.046 \\
\hline Rtn4rl1 & 3.1 & 0.011 \\
\hline Runx1 & -3.3 & 0.012 \\
\hline Ruvb/2 & -1.7 & 0.023 \\
\hline S100a10 & 2.4 & 0.005 \\
\hline S100a16 & 1.9 & 0.006 \\
\hline S100a3 & 2.3 & 0.044 \\
\hline S100a4 & 4.3 & 0.007 \\
\hline S100a6 & 4.5 & 0.002 \\
\hline Sag & 36.1 & 0.026 \\
\hline Sag & 36.1 & 0.026 \\
\hline Sag & 36.1 & 0.026 \\
\hline Sat1 & 1.7 & 0.008 \\
\hline Sat1 & 1.7 & 0.008 \\
\hline Sat1 & 1.7 & 0.008 \\
\hline Saxo2 & 331.9 & 0.017 \\
\hline Sbds & 1.7 & 0.016 \\
\hline Sbf1 & 1.8 & 0.034 \\
\hline Sbsn & 13.7 & 0.002 \\
\hline Scap & 1.8 & 0.028 \\
\hline Scara5 & 11.9 & 0.001 \\
\hline Scd2 & -2.1 & 0.008 \\
\hline Scfd1 1 & -1.8 & 0.002 \\
\hline Scg 5 & 331.0 & 0.004 \\
\hline Scgb1a1 & 383.4 & 0.005 \\
\hline $\operatorname{Scn} 2 b$ & -11.1 & 0.039 \\
\hline Scube3 & -33.8 & 0.023 \\
\hline$S d c b p$ & -1.5 & 0.026 \\
\hline Sdcbp2 & -144.5 & 0.041 \\
\hline Sdha & -2.0 & 0.002 \\
\hline Sdr16c5 & 259.0 & 0.013 \\
\hline $\operatorname{Sec} 13$ & -1.7 & 0.002 \\
\hline $\operatorname{Sec} 14 / 1$ & 3.1 & 0.000 \\
\hline $\operatorname{Sec} 22 b$ & -2.3 & 0.000 \\
\hline Sec23ip & -2.1 & 0.003 \\
\hline $\operatorname{Sec} 24 a$ & -3.9 & 0.017 \\
\hline Sec61a2 & -2.3 & 0.002 \\
\hline Selk & 1.8 & 0.004 \\
\hline Selt & -1.6 & 0.002 \\
\hline Sema3e & 37.2 & 0.032 \\
\hline Sema4b & -3.0 & 0.004 \\
\hline Serp1 & -2.0 & 0.000 \\
\hline
\end{tabular}




\begin{tabular}{|c|c|c|}
\hline Serpinb10 & 18.3 & 0.037 \\
\hline Serpinb2 & 549.6 & 0.001 \\
\hline Serpinb8 & 331.2 & 0.000 \\
\hline Serpinb9 & -2.3 & 0.022 \\
\hline Serpine1 & 7.0 & 0.001 \\
\hline Serpine2 & -2.1 & 0.022 \\
\hline Sesn 1 & -2.3 & 0.011 \\
\hline Set & -1.8 & 0.009 \\
\hline $5 f 3 a 2$ & -1.9 & 0.017 \\
\hline$S f 3 b 4$ & -1.6 & 0.037 \\
\hline Sfi1 & 2.2 & 0.026 \\
\hline Sfmbt2 & -147.8 & 0.038 \\
\hline Sftpc & 117.9 & 0.019 \\
\hline Sfxn1 & -4.0 & 0.003 \\
\hline Sfxn3 & 1.5 & 0.012 \\
\hline Sgcd & -2.0 & 0.036 \\
\hline Sgp/1 & -6.0 & 0.010 \\
\hline $\operatorname{Sh} 2 d 2 a$ & -375.9 & 0.009 \\
\hline Sh3glb2 & 2.2 & 0.001 \\
\hline Shc4 & 92.0 & 0.022 \\
\hline Shmt1 & -7.7 & 0.007 \\
\hline Shpk & 561.9 & 0.000 \\
\hline Shtn1 & 14.8 & 0.005 \\
\hline Siglec10 & -20.9 & 0.010 \\
\hline Sirt3 & 4.8 & 0.000 \\
\hline Sirt4 & 2.8 & 0.038 \\
\hline Sit1 & -11.4 & 0.033 \\
\hline Sit1,S/c6a2O & $\# N / A$ & $\# N / A$ \\
\hline Skp2 & -2.3 & 0.033 \\
\hline Slamf7 & -169.8 & 0.005 \\
\hline Slbp & -1.6 & 0.042 \\
\hline S/c12a4 & 1.7 & 0.020 \\
\hline Slc13a5 & 3.6 & 0.029 \\
\hline S/c15a2 & 78.1 & 0.010 \\
\hline S/c15a3 & 2.6 & 0.020 \\
\hline Slc16a1 & -6.2 & 0.001 \\
\hline Slc16a13 & 3.9 & 0.036 \\
\hline Slc16a14 & 45.4 & 0.036 \\
\hline Slc16a2 & -5.1 & 0.026 \\
\hline Slc1a1 & 167.2 & 0.007 \\
\hline Slc1a2 & 244.6 & 0.008 \\
\hline Slc1a3 & -5.5 & 0.000 \\
\hline Slc1a6 & -35.1 & 0.014 \\
\hline S/c24a4 & -21.9 & 0.032 \\
\hline$S / c 25 a 23$ & 44.0 & 0.019 \\
\hline Slc25a25 & -2.9 & 0.008 \\
\hline
\end{tabular}




\begin{tabular}{|c|c|c|}
\hline Slc25a28 & 1.9 & 0.002 \\
\hline Slc25a46 & -1.8 & 0.013 \\
\hline S/c26a6 & 4.1 & 0.013 \\
\hline S/c28a1 & 259.0 & 0.018 \\
\hline S/c28a3 & 124.1 & 0.009 \\
\hline Slc30a10 & -41.1 & 0.038 \\
\hline S/c30a3 & -279.3 & 0.012 \\
\hline Slc30a6 & -2.3 & 0.014 \\
\hline Slc30a7 & -2.0 & 0.021 \\
\hline Slc35e4 & 2.3 & 0.008 \\
\hline Slc39a1 & 3.1 & 0.021 \\
\hline Slc39a14 & 2.0 & 0.048 \\
\hline S/c39a3 & 2.7 & 0.000 \\
\hline S/c39a8 & -2.4 & 0.008 \\
\hline Slc43a2 & 3.4 & 0.006 \\
\hline Slc4ag & 320.0 & 0.005 \\
\hline S/c52a3 & 45.5 & 0.029 \\
\hline Slc5a5 & -307.9 & 0.015 \\
\hline Slc5a9 & 248.0 & 0.027 \\
\hline Slc6a8 & 2.6 & 0.007 \\
\hline Slc7a10 & -229.0 & 0.018 \\
\hline Slc7a3 & 60.1 & 0.042 \\
\hline Slc8b1 & 3.2 & 0.002 \\
\hline Slc9a3 & 83.1 & 0.011 \\
\hline $5 / c 9 a 8$ & -5.8 & 0.011 \\
\hline Slc9a9 & -2.7 & 0.025 \\
\hline S/co4a1 & 16.9 & 0.037 \\
\hline Slit3 & 2.5 & 0.002 \\
\hline Slmo2 & -1.8 & 0.001 \\
\hline$S \mid x 1 b$ & 2.3 & 0.001 \\
\hline Smad2 & -2.1 & 0.009 \\
\hline Smad6 & 1.9 & 0.044 \\
\hline Smad7 & 2.6 & 0.012 \\
\hline Smagp & 2.1 & 0.033 \\
\hline Smarcc1 & -2.3 & 0.004 \\
\hline Smarcd1 & -1.6 & 0.034 \\
\hline Smpd2 & 1.9 & 0.028 \\
\hline Snai2 & -2.4 & 0.006 \\
\hline Snai3 & 192.9 & 0.009 \\
\hline Snca & -7.8 & 0.031 \\
\hline Snn & -2.3 & 0.047 \\
\hline Snrpd2 & 1.6 & 0.042 \\
\hline Snta1 & 2.0 & 0.005 \\
\hline Sntb1 & 83.1 & 0.018 \\
\hline Sntg2 & -216.3 & 0.019 \\
\hline Snx6 & -1.7 & 0.000 \\
\hline
\end{tabular}




\begin{tabular}{|c|c|c|}
\hline $\operatorname{Sn} \times 9$ & -2.1 & 0.021 \\
\hline Soat1 & -11.8 & 0.000 \\
\hline Sox12 & -2.0 & 0.050 \\
\hline Sp9 & -6.4 & 0.018 \\
\hline Spib & -22.8 & 0.001 \\
\hline Spn & 9.9 & 0.002 \\
\hline Spn & 9.9 & 0.002 \\
\hline Spp1 & 7.7 & 0.002 \\
\hline Spp1 & 7.7 & 0.002 \\
\hline Spred3 & 86.8 & 0.011 \\
\hline Sprr1a & 2654.6 & 0.001 \\
\hline Spry1 & 2.1 & 0.029 \\
\hline Spsb1 & -4.0 & 0.018 \\
\hline Spsb4 & -59.9 & 0.007 \\
\hline Spta1 & -7.7 & 0.043 \\
\hline Sptbn1 & 1.8 & 0.027 \\
\hline Srd5a1 & -14.7 & 0.006 \\
\hline Srebf 2 & 1.8 & 0.000 \\
\hline Srf & 2.6 & 0.005 \\
\hline Srp14 & 1.6 & 0.002 \\
\hline Srpk3 & -104.9 & 0.001 \\
\hline Srprb & -1.6 & 0.044 \\
\hline Srrm2 & 1.9 & 0.023 \\
\hline Srsf1 & -1.5 & 0.023 \\
\hline Srsf11 & 1.8 & 0.005 \\
\hline Srsf 4 & -1.7 & 0.045 \\
\hline Srsf5 & -2.3 & 0.000 \\
\hline Sspo & 171.3 & 0.015 \\
\hline Sstr2 & 71.9 & 0.028 \\
\hline St14 & 2.7 & 0.033 \\
\hline St3gal2 & 1.9 & 0.004 \\
\hline St6galnac2 & -2.5 & 0.001 \\
\hline St8sia2 & -438.7 & 0.005 \\
\hline Stac2 & -289.1 & 0.012 \\
\hline Stambp & -2.3 & 0.010 \\
\hline Stard7 & -3.4 & 0.013 \\
\hline Steap3 & 1.9 & 0.032 \\
\hline Stip1 & -1.7 & 0.049 \\
\hline Stip1 & -1.7 & 0.049 \\
\hline Stk26 & -17.3 & 0.009 \\
\hline Stk35 & -3.6 & 0.014 \\
\hline Stmn2 & 69.6 & 0.043 \\
\hline Strada & -2.0 & 0.034 \\
\hline$S t t 3 b$ & -3.0 & 0.003 \\
\hline Stx 6 & -1.7 & 0.047 \\
\hline Stx 7 & -2.5 & 0.011 \\
\hline
\end{tabular}




\begin{tabular}{|c|c|c|}
\hline Sulf1 & 3.6 & 0.001 \\
\hline Sult1a1 & 2.7 & 0.047 \\
\hline Sult $2 b 1$ & 119.1 & 0.023 \\
\hline Sumf2 & -1.8 & 0.038 \\
\hline Sumo1 & -1.6 & 0.000 \\
\hline Sumo2 & -1.7 & 0.014 \\
\hline Suv420h1 & 2.0 & 0.014 \\
\hline$S v 2 b$ & 69.2 & 0.005 \\
\hline Svil & 2.4 & 0.005 \\
\hline Swt1 & 2.1 & 0.019 \\
\hline Sympk & -1.9 & 0.033 \\
\hline Syn3 & -170.5 & 0.023 \\
\hline Syndig1 & 12.4 & 0.044 \\
\hline Syne3 & 58.2 & 0.001 \\
\hline Synm & 4.3 & 0.011 \\
\hline Syt1 & 101.3 & 0.020 \\
\hline Syt17 & 36.4 & 0.040 \\
\hline Syt4 & -47.4 & 0.042 \\
\hline Syt6 & -100.7 & 0.028 \\
\hline Syt8 & 189.1 & 0.019 \\
\hline Syvn1 & -1.5 & 0.033 \\
\hline Tacc1 & 1.6 & 0.014 \\
\hline Tacr1 & 250.9 & 0.011 \\
\hline Tacstd2 & 475.5 & 0.007 \\
\hline Taf1a & -4.5 & 0.016 \\
\hline Tafgb & -1.9 & 0.038 \\
\hline Tars & -2.2 & 0.020 \\
\hline Tas1r1 & -96.2 & 0.027 \\
\hline Tatdn2 & 1.7 & 0.029 \\
\hline Tbc1d10a & 1.7 & 0.024 \\
\hline$T b c 1 d 10 b$ & -1.7 & 0.026 \\
\hline$T b c 1 d 20$ & -2.5 & 0.004 \\
\hline Tbp & -2.3 & 0.006 \\
\hline$T b \times 15$ & -75.4 & 0.045 \\
\hline$T b x a 2 r$ & -3.4 & 0.004 \\
\hline$T c f 12$ & -2.3 & 0.007 \\
\hline Tcirg1 & 2.1 & 0.015 \\
\hline Tcp1 & -2.3 & 0.007 \\
\hline$T d h$ & 149.3 & 0.015 \\
\hline$T d p 2$ & 2.1 & 0.007 \\
\hline Tefm & -6.9 & 0.000 \\
\hline Tenm2 & -36.6 & 0.049 \\
\hline Tep1 & 2.8 & 0.004 \\
\hline Tesk1 & 1.8 & 0.008 \\
\hline Tesk2 & -6.4 & 0.030 \\
\hline$T f$ & -5.4 & 0.010 \\
\hline
\end{tabular}




\begin{tabular}{|c|c|c|}
\hline$T f$ & -5.4 & 0.010 \\
\hline Tfap2e & 93.3 & 0.038 \\
\hline$T f b 1 m$ & 1.9 & 0.045 \\
\hline Tgif2 & -3.6 & 0.048 \\
\hline Thbs4 & 4.4 & 0.001 \\
\hline Thoc3 & -1.6 & 0.022 \\
\hline Thoc5 & -2.1 & 0.008 \\
\hline Thrap3 & -1.8 & 0.025 \\
\hline Thsd7b & -50.1 & 0.016 \\
\hline Tiam1 & 45.1 & 0.000 \\
\hline Tifa & -7.3 & 0.000 \\
\hline Timd 2 & 127.6 & 0.002 \\
\hline Timm13 & 1.8 & 0.011 \\
\hline Timm8b & 1.6 & 0.043 \\
\hline Tiprl & -2.1 & 0.003 \\
\hline Tjp1 & 1.9 & 0.045 \\
\hline$T k f c$ & -2.6 & 0.028 \\
\hline Tle1 & -2.8 & 0.005 \\
\hline Tle4 & -2.2 & 0.016 \\
\hline TIr2 & -4.3 & 0.033 \\
\hline TIr4 & 248.7 & 0.000 \\
\hline Tmed2 & -1.8 & 0.002 \\
\hline Tmeff1 & -3.0 & 0.004 \\
\hline Tmem109 & 1.6 & 0.010 \\
\hline Tmem135 & -2.7 & 0.042 \\
\hline Tmem170b & 365.8 & 0.003 \\
\hline Tmem178a & -15.2 & 0.010 \\
\hline Tmem208 & 1.7 & 0.017 \\
\hline Tmem259 & 2.0 & 0.009 \\
\hline Tmem33 & 2.0 & 0.021 \\
\hline Tmem43 & -1.8 & 0.004 \\
\hline Tmem71 & -23.7 & 0.034 \\
\hline Tmem80 & 2.1 & 0.039 \\
\hline Tmem86b & -12.1 & 0.021 \\
\hline Tmem9 & -1.9 & 0.001 \\
\hline Tmod4 & 22.6 & 0.032 \\
\hline Tmprss11d & 394.4 & 0.009 \\
\hline Tmprss3 & -99.9 & 0.014 \\
\hline Tmprss6 & -94.3 & 0.029 \\
\hline Tmprss9 & 12.5 & 0.040 \\
\hline Tmsb4x & 2.0 & 0.002 \\
\hline Tmtc2 & -4.1 & 0.017 \\
\hline $\operatorname{Tm} \times 1$ & -1.9 & 0.044 \\
\hline Tnfaip1 & -2.3 & 0.001 \\
\hline Tnfrsf13b & -52.3 & 0.024 \\
\hline Tnfrsf14 & 18.2 & 0.018 \\
\hline
\end{tabular}




\begin{tabular}{|c|c|c|}
\hline Tnfrsf18 & -240.7 & 0.012 \\
\hline Tnfrsf19 & -3.0 & 0.001 \\
\hline Tnfsf13b & -98.6 & 0.029 \\
\hline Tnmd & -5.4 & 0.003 \\
\hline Tnnc1 & -38.0 & 0.003 \\
\hline Tnnc2 & 964.7 & 0.002 \\
\hline Tnni1 & 45.5 & 0.038 \\
\hline Tnrc18 & 2.2 & 0.015 \\
\hline Tnrc6b & 2.2 & 0.006 \\
\hline Tns3 & 1.8 & 0.030 \\
\hline Tob1 & 2.5 & 0.014 \\
\hline Tom1/1 & -3.4 & 0.008 \\
\hline Tox & 12.5 & 0.045 \\
\hline Tox4 & -2.0 & 0.002 \\
\hline Tp53i13 & 1.6 & 0.009 \\
\hline Tp53inp2 & 1.7 & 0.031 \\
\hline Tpm1 & -2.2 & 0.000 \\
\hline Tpm4 & -2.2 & 0.001 \\
\hline Tpp1 & 1.8 & 0.037 \\
\hline Tpp1 & 1.8 & 0.037 \\
\hline Tppp3 & 3.5 & 0.018 \\
\hline Tpra1 & 1.6 & 0.012 \\
\hline $\operatorname{Tra2b}$ & -1.5 & 0.010 \\
\hline Trappc1 & -1.5 & 0.003 \\
\hline Trappc4 & 1.9 & 0.002 \\
\hline Trex1 & 2.3 & 0.002 \\
\hline Trib2 & 2.4 & 0.002 \\
\hline Trim13 & -17.1 & 0.020 \\
\hline Trim21 & -46.9 & 0.012 \\
\hline Trim 37 & -2.7 & 0.038 \\
\hline Trim47 & 2.3 & 0.002 \\
\hline Trim54 & 187.0 & 0.013 \\
\hline Trim59 & -2.1 & 0.040 \\
\hline Trim69 & 217.0 & 0.014 \\
\hline Trim8 & 1.5 & 0.022 \\
\hline Trip6 & 2.0 & 0.003 \\
\hline Trmt10b & 2.0 & 0.030 \\
\hline Trmt10c & -1.6 & 0.036 \\
\hline Trpm1 & 105.4 & 0.018 \\
\hline Trpm8 & -100.5 & 0.019 \\
\hline Trpv6 & 116.7 & 0.013 \\
\hline Trub1 & -6.7 & 0.010 \\
\hline Tsacc & 99.9 & 0.018 \\
\hline Tspan17 & 1.9 & 0.048 \\
\hline Tspan6 & -1.8 & 0.002 \\
\hline Tspo & 2.4 & 0.001 \\
\hline
\end{tabular}




\begin{tabular}{|c|c|c|}
\hline Tspyl1 & -1.5 & 0.014 \\
\hline Ttbk2 & 4.0 & 0.027 \\
\hline Ttc12 & 75.4 & 0.013 \\
\hline Ttc17 & 2.6 & 0.033 \\
\hline$T t f 2$ & 2.0 & 0.031 \\
\hline$T t / l 10$ & 112.0 & 0.025 \\
\hline$T t / l 3$ & 11.4 & 0.043 \\
\hline Ttyh3 & -1.7 & 0.012 \\
\hline Tuba8 & 199.0 & 0.000 \\
\hline Tubb2a & 1.9 & 0.011 \\
\hline Tubb2a & 1.9 & 0.011 \\
\hline Tubb4a & 222.6 & 0.014 \\
\hline Tubgcp3 & 2.8 & 0.006 \\
\hline Tusc2 & 1.6 & 0.003 \\
\hline TxIna & -1.9 & 0.020 \\
\hline Txndc5 & -1.5 & 0.021 \\
\hline Tyms & -2.2 & 0.025 \\
\hline Tyrobp & 2.3 & 0.035 \\
\hline Uba1 & -1.5 & 0.032 \\
\hline Uba2 & -3.0 & 0.020 \\
\hline Ubac2 & -2.0 & 0.000 \\
\hline Ubash3a & -67.6 & 0.025 \\
\hline$U b c$ & 1.7 & 0.002 \\
\hline Ubd & -72.8 & 0.047 \\
\hline Ube2v2 & -1.8 & 0.003 \\
\hline Ubxn2b & -7.3 & 0.011 \\
\hline Ubxn6 & 1.6 & 0.004 \\
\hline Uchl1 & -3.3 & 0.001 \\
\hline Ucp3 & 494.6 & 0.008 \\
\hline$U g c g$ & -2.5 & 0.011 \\
\hline Ugdh & -1.8 & 0.015 \\
\hline Uhrf1 & -7.7 & 0.015 \\
\hline Umps & -1.8 & 0.003 \\
\hline Unc45a & 2.3 & 0.000 \\
\hline Unc5a & 770.6 & 0.007 \\
\hline Unc5c & 3.7 & 0.010 \\
\hline Unc5d & -35.1 & 0.046 \\
\hline Uqcc1 & -1.8 & 0.039 \\
\hline Uqcr11 & 1.8 & 0.005 \\
\hline Uqcrq & 1.6 & 0.034 \\
\hline Urb1 & 3.3 & 0.033 \\
\hline Use1 & 2.0 & 0.003 \\
\hline Use1,Ube2z & $\# N / A$ & $\# \mathrm{~N} / \mathrm{A}$ \\
\hline Usmg5 & 2.0 & 0.028 \\
\hline Usp11 & -3.7 & 0.000 \\
\hline Usp14 & -1.5 & 0.026 \\
\hline
\end{tabular}




\begin{tabular}{|c|c|c|}
\hline Usp19 & 1.8 & 0.041 \\
\hline Usp24 & 2.6 & 0.019 \\
\hline Usp33 & 2.5 & 0.024 \\
\hline Usp36 & 2.2 & 0.030 \\
\hline Vac14 & -2.1 & 0.009 \\
\hline Vamp5 & 2.2 & 0.015 \\
\hline Vamp8 & 2.0 & 0.000 \\
\hline Vapb & -2.0 & 0.006 \\
\hline Vil1 & -119.4 & 0.031 \\
\hline Vim & 1.9 & 0.005 \\
\hline Vipas39 & 2.2 & 0.006 \\
\hline Vmac & -3.0 & 0.032 \\
\hline Vps13a & 4.7 & 0.008 \\
\hline Vps13d & 3.3 & 0.002 \\
\hline Vps26a & -2.1 & 0.021 \\
\hline Vps35 & -1.7 & 0.014 \\
\hline Vps37b & -2.1 & 0.013 \\
\hline Vps41 & -2.4 & 0.000 \\
\hline Vps52 & -1.8 & 0.048 \\
\hline Vps53 & 1.9 & 0.033 \\
\hline Vrk2 & -3.5 & 0.012 \\
\hline Vti1a & -4.4 & 0.001 \\
\hline Wars2 & -5.0 & 0.047 \\
\hline Wasf2 & 1.6 & 0.028 \\
\hline Wasl & 1.6 & 0.041 \\
\hline Wdfy3 & 2.8 & 0.009 \\
\hline$W d r 5$ & -1.7 & 0.035 \\
\hline Wdr6 & -1.8 & 0.046 \\
\hline$W d r 75$ & -2.9 & 0.000 \\
\hline Wisp2 & 7.6 & 0.020 \\
\hline WIs & -1.6 & 0.034 \\
\hline Wnt11 & -3.2 & 0.009 \\
\hline Wnt5b & 2.6 & 0.004 \\
\hline Wrap73 & 1.7 & 0.042 \\
\hline$X k$ & -35.6 & 0.018 \\
\hline$X k r 4$ & 33.9 & 0.034 \\
\hline$X k r 6$ & 32.9 & 0.034 \\
\hline Xpo1 & -2.2 & 0.025 \\
\hline Xpo6 & -2.2 & 0.008 \\
\hline Xpot & -2.2 & 0.012 \\
\hline $\operatorname{xrcc1}$ & 1.8 & 0.002 \\
\hline $\operatorname{xrcc5}$ & -2.6 & 0.001 \\
\hline Yaf2 & -1.6 & 0.015 \\
\hline Ykt6 & -2.6 & 0.006 \\
\hline Ylpm1 & 1.8 & 0.045 \\
\hline Ythdc1 & 2.0 & 0.025 \\
\hline
\end{tabular}




\begin{tabular}{|lrr|}
\hline Ywhab & -1.5 & 0.002 \\
\hline Ywhae & -1.7 & 0.000 \\
\hline Ywhag & 1.7 & 0.014 \\
\hline Ywhaz & -1.7 & 0.004 \\
\hline Zbed3 & -1.7 & 0.036 \\
\hline Zbp1 & -40.1 & 0.026 \\
\hline Zbp1 & -40.1 & 0.026 \\
\hline Zbtb16 & 337.2 & 0.001 \\
\hline Zbtb7c & 3.5 & 0.018 \\
\hline Zc3h10 & 2.6 & 0.002 \\
\hline Zc3h14 & -1.9 & 0.010 \\
\hline Zcchc12 & -3.4 & 0.008 \\
\hline Zcrb1 & 1.5 & 0.025 \\
\hline Zdhhc20 & -2.4 & 0.001 \\
\hline Zdhhc6 & -1.9 & 0.012 \\
\hline Zfp2 & 247.2 & 0.005 \\
\hline Zfp263 & -2.3 & 0.019 \\
\hline Zfp280b & 9.6 & 0.029 \\
\hline Zfp394 & 2.1 & 0.045 \\
\hline Zfp410 & -1.7 & 0.030 \\
\hline Zfp422 & -1.9 & 0.003 \\
\hline Zfp467 & 2.3 & 0.031 \\
\hline Zfp483 & -114.6 & 0.006 \\
\hline Zfp513 & 184.5 & 0.008 \\
\hline Zfp521 & -1.1 & 0.023 \\
\hline Zfp641 & 1.8 & 0.041 \\
\hline Zfp68 & -2.2 & 0.018 \\
\hline Zgpat & 27.7 & 0.033 \\
\hline Zim1 & -2.0 & 0.012 \\
\hline Zmpste24 & -290.1 & 0.027 \\
\hline Znhit1 & -5.5 & 0.014 \\
\hline Znrd1 & 1.9 & 0.012 \\
\hline Zpbp & \\
\hline Zswim5 & \\
\hline
\end{tabular}




\section{Appendix Table 2}

The original proteomic analysis data of stretched PDL cells showed in Figure 4.

\begin{tabular}{|c|c|c|c|}
\hline Accession & Gene & $\begin{array}{l}\text { LFQ } \\
\text { intensity } \\
\text { Control }\end{array}$ & $\begin{array}{l}\text { LFQ } \\
\text { intensity } \\
\text { Stretched }\end{array}$ \\
\hline A0A024R442 & DNPEP & 0 & 20.9996891 \\
\hline A0A075B785 & RELCH & 0 & 19.76844597 \\
\hline A0A087WTA8 & COL1A2 & 25.22523308 & 26.31858635 \\
\hline A0A087WVZ9 & POLR2E & 0 & 20.16643715 \\
\hline A0A087WX58 & HDGFL2 & 0 & 19.65448952 \\
\hline A0A087WXC5 & NDUFA10 & 22.09055138 & 0 \\
\hline A0A087WYV8 & FBN2 & 19.73524284 & 20.74386215 \\
\hline AOAOAOMRE1 & EXOC7 & 0 & 20.59914207 \\
\hline AOAOAOMSK4 & GPSM1 & 21.75103188 & 20.19568443 \\
\hline AOAOAOMTN9 & FDXR & 0 & 20.98454094 \\
\hline AOAOAOMTR7 & RNF213 & 23.30827522 & 24.40379715 \\
\hline A0A0A6YYAO & $\begin{array}{l}\text { TMED7- } \\
\text { TICAM2 } \\
\end{array}$ & 21.09119797 & 22.54521751 \\
\hline A0A0B4J2AO & None & 0 & 19.78540421 \\
\hline A0A0C4DFM1 & TM9SF4 & 21.73148537 & 20.58682823 \\
\hline AOAOC4DG40 & SYNE1 & 23.24419022 & 24.31257439 \\
\hline A0A0G2JNZ5 & GBA & 0 & 22.26023293 \\
\hline A0AOU1RR22 & PACSIN2 & 0 & 22.15375519 \\
\hline A0A1B0GTU1 & ZC3H11B & 0 & 17.82059097 \\
\hline A0A1B0GWF2 & STXBP1 & 20.82973862 & 22.27295685 \\
\hline A0A1W2PR68 & ME2 & 0 & 19.77781677 \\
\hline A0A2R8Y430 & GSS & 0 & 22.14416885 \\
\hline A0A2R8YF43 & CSNK2A1 & 22.16628456 & 21.01202202 \\
\hline A0A3B3IS01 & DARS2 & 19.57568359 & 0 \\
\hline B1ALD9 & POSTN & 21.65460205 & 20.32410622 \\
\hline B1ANM7 & FAF1 & 21.37023354 & 20.30463219 \\
\hline B4E1E4 & EIF4E2 & 0 & 19.40582275 \\
\hline B8ZZC5 & GLS & 20.10686874 & 0 \\
\hline C9JBI3 & PSPH & 0 & 18.98061371 \\
\hline C9JJ54 & WDFY1 & 19.68905258 & 0 \\
\hline E7EWK3 & DHX36 & 0 & 20.04686737 \\
\hline E9PB90 & HK2 & 22.67480278 & 21.65110207 \\
\hline E9PF19 & TBL2 & 21.46188927 & 20.36474228 \\
\hline E9PGM1 & EIF4G1 & 26.33698273 & 24.98767471 \\
\hline E9PHV5 & ITPRID2 & 19.72468948 & 20.93531418 \\
\hline E9PKU7 & GANAB & 0 & 20.05959702 \\
\hline E9PLK3 & NPEPPS & 24.54639626 & 25.80466843 \\
\hline E9PNU4 & STX5 & 0 & 20.20741081 \\
\hline E9PQP3 & ARFGAP2 & 0 & 19.8045311 \\
\hline F2Z2X4 & XPO4 & 0 & 19.36851883 \\
\hline F5H4B6 & ALDH16A1 & 20.39947319 & 0 \\
\hline
\end{tabular}




\begin{tabular}{|c|c|c|c|}
\hline F5H5N1 & NDUFS7 & 0 & 20.1316967 \\
\hline F8VSC5 & SCYL2 & 0 & 20.32432556 \\
\hline F8W020 & NAP1L1 & 23.19088554 & 24.30340576 \\
\hline F8W1F5 & FMNL3 & 0 & 19.6111908 \\
\hline F8W808 & NAA10 & 21.89081955 & 20.4582386 \\
\hline F8W9T3 & SNX4 & 0 & 21.89969635 \\
\hline G3V126 & ATP6V1H & 0 & 18.98281479 \\
\hline G3V529 & DDX24 & 0 & 18.44596863 \\
\hline G5E9S8 & KLC1 & 23.14177132 & 24.31741333 \\
\hline HOYDP7 & MRPL49 & 0 & 20.50581551 \\
\hline J3KTF8 & ARHGDIA & 24.56307983 & 25.60501099 \\
\hline J3QLR8 & MRPS23 & 0 & 19.49917221 \\
\hline J3QR09 & RPL19 & 22.55912781 & 23.77283669 \\
\hline M0R026 & ILVBL & 21.18252945 & 19.68642235 \\
\hline MOR208 & CLPP & 20.40789795 & 22.10980606 \\
\hline 000267 & SUPT5H & 0 & 20.00237083 \\
\hline 000754 & MAN2B1 & 0 & 20.7157383 \\
\hline 014818 & PSMA7 & 24.01154327 & 25.14390373 \\
\hline 015173 & PGRMC2 & 22.74915123 & 23.92315865 \\
\hline 015270 & SPTLC2 & 0 & 19.53425407 \\
\hline 015427 & SLC16A3 & 23.23410606 & 22.17292023 \\
\hline 015460 & P4HA2 & 24.34638023 & 26.01073265 \\
\hline 043390 & HNRNPR & 21.59418488 & 23.08321571 \\
\hline 060502 & OGA & 0 & 21.01352119 \\
\hline 060762 & DPM1 & 19.60188293 & 20.8239994 \\
\hline 075534 & CSDE1 & 21.91338539 & 22.95976639 \\
\hline 075643 & SNRNP200 & 26.44395256 & 25.00906754 \\
\hline 075844 & ZMPSTE24 & 21.97571754 & 20.68953133 \\
\hline 075962 & TRIO & 20.65394783 & 21.80644417 \\
\hline 075976 & CPD & 0 & 21.04092979 \\
\hline 094804 & STK10 & 0 & 17.59433937 \\
\hline 095197 & RTN3 & 22.27332687 & 20.819561 \\
\hline 095248 & SBF1 & 0 & 21.51123238 \\
\hline 095810 & CAVIN2 & 0 & \begin{tabular}{|l}
19.57767677 \\
\end{tabular} \\
\hline 095881 & TXNDC12 & 0 & 20.94177628 \\
\hline 096005 & CLPTM1 & 22.37983513 & 21.17718506 \\
\hline P02452 & COL1A1 & 26.02312088 & 28.7821312 \\
\hline P02461 & COL3A1 & 21.85866928 & 23.9216156 \\
\hline P02545 & LMNA & 28.88495064 & 29.89865112 \\
\hline P02792 & FTL & 23.62644958 & 22.54158401 \\
\hline P04080 & CSTB & 23.54957199 & 22.35901451 \\
\hline P04632 & CAPNS1 & 24.03204155 & 25.27476311 \\
\hline P04792 & HSPB1 & 26.62714577 & 27.82420158 \\
\hline P04818 & TYMS & 21.41142082 & 20.24898911 \\
\hline P05997 & COL5A2 & 19.73646545 & 21.18924332 \\
\hline P07814 & EPRS & 24.96146393 & 26.25281143 \\
\hline P08243 & ASNS & 22.13842964 & 23.32909775 \\
\hline
\end{tabular}




\begin{tabular}{|c|c|c|c|}
\hline P08574 & CYC1 & 0 & 20.90873909 \\
\hline P08648 & ITGA5 & 25.22574806 & 24.18737221 \\
\hline P09960 & LTA4H & 21.50149727 & 22.81188202 \\
\hline PODMV9 & HSPA1B & 29.0905323 & 27.32551575 \\
\hline P12081 & HARS & 24.30528641 & 25.34235001 \\
\hline P14923 & JUP & 20.95695114 & 0 \\
\hline P15104 & GLUL & 0 & 20.75287056 \\
\hline P16234 & PDGFRA & 0 & 20.9249897 \\
\hline P16930 & FAH & 21.85178566 & 20.74779892 \\
\hline P17066 & HSPA6 & 28.77596092 & 27.75748062 \\
\hline P19174 & PLCG1 & 0 & 19.5958519 \\
\hline P19474 & TRIM21 & 0 & 19.35287476 \\
\hline P20908 & COL5A1 & 21.16090965 & 22.27810097 \\
\hline P21964 & COMT & 22.38226509 & 23.46811867 \\
\hline P23381 & WARS & 23.40743256 & 24.44335365 \\
\hline P24928 & POLR2A & 20.53763199 & 19.08085442 \\
\hline P26022 & PTX3 & 0 & 19.87612724 \\
\hline P26038 & MSN & 28.74890327 & 29.82072258 \\
\hline P26373 & RPL13 & 25.4160614 & 26.60385323 \\
\hline P27348 & YWHAQ & 26.22118187 & 27.4228611 \\
\hline P28288 & ABCD3 & 21.29283142 & 19.83644104 \\
\hline P30038 & ALDH4A1 & 0 & 18.69149208 \\
\hline P30405 & PPIF & 23.03175545 & 22.02116776 \\
\hline P31153 & MAT2A & 23.43478966 & 22.30924797 \\
\hline P32119 & PRDX2 & 25.56575584 & 24.35137749 \\
\hline P32455 & GBP1 & 20.91342163 & 22.04620171 \\
\hline P35354 & PTGS2 & 22.50054932 & 20.74246407 \\
\hline P35573 & AGL & 0 & 18.90124321 \\
\hline P42167 & TMPO & 20.45352364 & 21.76198578 \\
\hline P43487 & RANBP1 & 22.69242859 & 23.94628143 \\
\hline P46821 & MAP1B & 27.4512043 & 26.03632545 \\
\hline P46937 & YAP1 & 21.46173859 & 22.57327652 \\
\hline P46940 & IQGAP1 & 27.27382088 & 28.48834229 \\
\hline P47914 & RPL29 & 23.20067596 & 24.29459953 \\
\hline P49748 & ACADVL & 25.07842827 & 26.20894051 \\
\hline P50395 & GDI2 & 26.025383 & 27.03128433 \\
\hline P50416 & CPT1A & 23.39610672 & 22.20943451 \\
\hline P51809 & VAMP7 & 0 & 19.97687149 \\
\hline P51970 & NDUFA8 & 21.54297638 & 19.81770515 \\
\hline P52630 & STAT2 & 20.81151009 & 21.92524338 \\
\hline P55084 & HADHB & 25.01979446 & 23.79213333 \\
\hline P56545 & СТВР2 & 21.70956612 & 22.81381989 \\
\hline P57764 & GSDMD & 0 & 19.04390907 \\
\hline P61586 & RHOA & 0 & 22.79070282 \\
\hline P61619 & SEC61A1 & 24.79808044 & 23.63533401 \\
\hline P62826 & RAN & 25.3025341 & 26.37102509 \\
\hline P67809 & YBX1 & 25.56435966 & 24.45349884 \\
\hline
\end{tabular}




\begin{tabular}{|c|c|c|c|}
\hline P78559 & MAP1A & 23.87107658 & 24.99183273 \\
\hline Q00688 & FKBP3 & 21.51638603 & 23.73106956 \\
\hline Q04917 & YWHAH & 24.16622353 & 25.20988846 \\
\hline Q06124 & PTPN11 & 21.06716919 & 22.37581062 \\
\hline Q06203 & PPAT & 0 & 20.50057411 \\
\hline Q08378 & GOLGA3 & 21.67620277 & 22.77782059 \\
\hline Q12965 & MY01E & 20.13746071 & 21.31959343 \\
\hline Q13131 & PRKAA1 & 0 & 21.00422287 \\
\hline Q13242 & SRSF9 & 19.10469627 & 20.44909668 \\
\hline Q13596 & SNX1 & 21.8387661 & 23.32991982 \\
\hline Q14152 & EIF3A & 24.92718887 & 26.21811676 \\
\hline Q14696 & MESD & 19.84509277 & 21.00374222 \\
\hline Q14789 & GOLGB1 & 24.66871452 & 23.57080078 \\
\hline Q15021 & NCAPD2 & 0 & 20.3668766 \\
\hline Q15056 & EIF4H & 23.36826324 & 24.77660751 \\
\hline Q15075 & EEA1 & 23.31741333 & 24.69104385 \\
\hline Q15233 & NONO & 24.7138195 & 25.76789665 \\
\hline Q16134 & ETFDH & 21.16029549 & 0 \\
\hline Q16513 & PKN2 & 19.69333076 & 20.82150841 \\
\hline Q16658 & FSCN1 & 25.69144249 & 26.86714554 \\
\hline Q16778 & HIST2H2BE & 26.90644264 & 25.62419128 \\
\hline Q16822 & PCK2 & 22.51982117 & 24.02647972 \\
\hline Q16878 & CDO1 & 0 & 23.31451225 \\
\hline Q5JRG1 & NUP58 & 0 & 20.33123207 \\
\hline Q5T010 & GSN & 21.1754818 & 22.3467598 \\
\hline Q5VYK3 & ECPAS & 22.48892975 & 24.10093307 \\
\hline Q68CQ7 & GLT8D1 & 0 & 21.56592941 \\
\hline Q68E01 & INTS3 & 0 & 19.13560867 \\
\hline Q6P2E9 & EDC4 & 19.89511681 & 21.12760925 \\
\hline Q7Z3U7 & MON2 & 0 & 21.72558975 \\
\hline Q8IVF2 & AHNAK2 & 21.0956459 & 0 \\
\hline Q8IWJ2 & GCC2 & 20.04126358 & 21.07463455 \\
\hline Q8N129 & CNPY4 & 19.50589371 & 0 \\
\hline Q8TBA6 & GOLGA5 & 19.2819519 & 0 \\
\hline Q8TCT9 & HM13 & 25.04963684 & 24.03355408 \\
\hline Q8TDD1 & DDX54 & 0 & 19.40621758 \\
\hline Q8TEX9 & IPO4 & 21.96370506 & 23.04977798 \\
\hline Q8WU90 & ZC3H15 & 20.30273628 & 21.33576393 \\
\hline Q92575 & UBXN4 & 0 & 20.73073959 \\
\hline Q92629 & SGCD & 0 & 19.04788017 \\
\hline Q92734 & TFG & 23.73055267 & 24.79872322 \\
\hline Q92882 & OSTF1 & 20.70497513 & 21.89145088 \\
\hline Q96CG8 & CTHRC1 & 21.28263092 & 22.5556221 \\
\hline Q96CT7 & CCDC124 & 0 & 19.65881729 \\
\hline Q96JQ0 & DCHS1 & 18.9074192 & 0 \\
\hline Q96SB3 & PPP1R9B & 21.21299934 & 0 \\
\hline Q96TA1 & FAM129B & 26.7624321 & 24.93035126 \\
\hline
\end{tabular}




\begin{tabular}{|c|c|c|c|}
\hline Q99715 & COL12A1 & 25.5644474 & 27.04228592 \\
\hline Q99747 & NAPG & 0 & 20.63962364 \\
\hline Q99805 & TM9SF2 & 21.15961838 & 20.02431679 \\
\hline Q99832 & СCT7 & 25.16970634 & 26.43934822 \\
\hline Q9BPW8 & NIPSNAP1 & 0 & 20.66440201 \\
\hline Q9BQ67 & GRWD1 & 0 & 19.73229599 \\
\hline Q9BQS8 & FYCO1 & 20.9930687 & 22.06111526 \\
\hline Q9BRF8 & CPPED1 & 0 & 21.15165138 \\
\hline Q9BW60 & ELOVL1 & 22.21208 & 21.1392746 \\
\hline Q9BY44 & EIF2A & 22.04266739 & 20.94713783 \\
\hline Q9H1B7 & IRF2BPL & 0 & 18.87306595 \\
\hline Q9H223 & EHD4 & 0 & 20.26956558 \\
\hline Q9H2U2 & PPA2 & 0 & 21.18507385 \\
\hline Q9HAV7 & GRPEL1 & 20.83259964 & 22.38094521 \\
\hline Q9HB40 & SCPEP1 & 0 & 20.93675232 \\
\hline Q9HCLO & PCDH18 & 0 & 19.58913612 \\
\hline Q9HD45 & TM9SF3 & 22.06999016 & 20.69251251 \\
\hline Q9NRY4 & ARHGAP35 & 8 & 19.44497871 \\
\hline Q9NSD9 & FARSB & 22.56020164 & 24.20329285 \\
\hline Q9NUQ8 & ABCF3 & 0 & 19.8791523 \\
\hline Q9NV70 & EXOC1 & 19.37553596 & 0 \\
\hline Q9NVI7 & ATAD3A & 22.91378593 & 24.31319809 \\
\hline Q9NW15 & ANO10 & 0 & 20.39089584 \\
\hline Q9NX08 & COMMD8 & 0 & 20.09493828 \\
\hline Q9NXG2 & THUMPD1 & 0 & 21.14413834 \\
\hline Q9NZB2 & FAM120A & 25.2062397 & 23.61717224 \\
\hline Q9NZN4 & EHD2 & 25.39447212 & 26.43766594 \\
\hline Q9P2R3 & ANKFY1 & 21.45848846 & 22.65425301 \\
\hline Q9UBG0 & MRC2 & 23.40781975 & 24.75302315 \\
\hline Q9UH99 & SUN2 & 19.84743309 & 21.2696228 \\
\hline Q9UL25 & RAB21 & 21.68863487 & 22.91340256 \\
\hline Q9ULT8 & HECTD1 & 0 & 20.53107643 \\
\hline Q9UMX0 & UBQLN1 & 0 & 21.44955063 \\
\hline Q9UN70 & PCDHGC3 & 0 & 20.26647949 \\
\hline Q9UNW1 & MINPP1 & 0 & 20.22163963 \\
\hline Q9UQE7 & SMC3 & 22.4522171 & 21.36420822 \\
\hline Q9Y224 & RTRAF & 22.34708405 & 23.44113731 \\
\hline Q9Y230 & RUVBL2 & 23.94529915 & 24.95464706 \\
\hline Q9Y281 & CFL2 & 0 & 21.72425652 \\
\hline Q9Y2X3 & NOP58 & 0 & 21.9932766 \\
\hline Q9Y310 & RTCB & 23.71187782 & 24.85562134 \\
\hline Q9Y512 & SAMM50 & 0 & 21.21240616 \\
\hline Q9Y5S2 & CDC42BPB & 19.38237 & 20.63794518 \\
\hline Q9Y5S9 & RBM8A & 21.61867332 & 20.58389473 \\
\hline Q9Y608 & LRRFIP2 & 0 & 20.42070007 \\
\hline R4GNG3 & GIT2 & 0 & 19.97084808 \\
\hline S4R3Z2 & AKR1C3 & 21.77671814 & 0 \\
\hline
\end{tabular}




\section{Appendix Table 3}

The antibodies, primers and protein used in the study.

\begin{tabular}{|c|c|c|c|c|c|}
\hline \multicolumn{7}{|c|}{ Primary antibodies (Immunofluorescence) } \\
\hline Antigen & Figure & Diluting factor & Company & Cat. No. & Batch No. \\
\hline Notch 1 ICD & 2D & $1: 200$ & e-Bioscience & $14-5785-82$ & E04375-261 \\
\hline $\begin{array}{c}\text { Total } \\
\text { Notch1 }\end{array}$ & 2E & $1: 200$ & Cell Signalling & $4380 \mathrm{~s}$ & lot 2 \\
\hline Dl11 & 2F & $1: 200$ & R\&D Systems & AF5026 & \\
\hline Osteopontin & 2G & $1: 100$ & $\begin{array}{c}\text { Dr Larry fisher } \\
\text { (NIH) }\end{array}$ & $\begin{array}{c}\text { LF-166 } \\
\text { hOPN (C- } \\
\text { terminus) }\end{array}$ & \\
\hline Periostin & $\begin{array}{c}\text { 1C, 3H-J, } \\
\text { App. 2A }\end{array}$ & $1: 400$ & $\begin{array}{c}\text { Abcam } \\
\text { AB14041 }\end{array}$ & \\
\hline Notch 2 ICD & 2E & $1: 200$ & Sigma & SAB4502022 & 410353 \\
\hline Lamin A/C & 5B & $1: 200$ & Cell signalling & $4777 s$ & Lot 1 \\
\hline Lamin A/C & 5E & $1: 200$ & Santa Cruz & sc-20681 & A1116 \\
\hline
\end{tabular}

\begin{tabular}{|c|c|c|c|c|}
\hline \multicolumn{5}{|c|}{ Secondary antibodies (Immunofluorescence) } \\
\hline Target & Dilution & Company & Cat. No. & Lot \\
\hline $\begin{array}{c}\text { Alexa 568 } \\
\text { Donkey anti- } \\
\text { Mouse IgG }\end{array}$ & $1: 500$ & $\begin{array}{c}\text { Life } \\
\text { Technologies }\end{array}$ & A10037 & 1303018 \\
\hline $\begin{array}{c}\text { Alexa 568 } \\
\text { Donkey anti- } \\
\text { Rabbit IgG }\end{array}$ & $1: 500$ & $\begin{array}{c}\text { Life } \\
\text { Technologies }\end{array}$ & A10042 & 1964370 \\
\hline $\begin{array}{c}\text { Alexa 568 } \\
\text { Donkey anti- } \\
\text { Rabbit IgG }\end{array}$ & $1: 500$ & Abcam & Ab175470 & 1322311 \\
$\begin{array}{c}\text { Alexa 488 } \\
\text { Donkey anti- } \\
\text { Sheep IgG }\end{array}$ & $1: 300$ & $\begin{array}{c}\text { Life } \\
\text { Tlexa 488 }\end{array}$ & A11015 & 1796361 \\
$\begin{array}{c}\text { Donkey anti- } \\
\text { Mouse IgG }\end{array}$ & $1: 300$ & $\begin{array}{c}\text { Life } \\
\text { Technologies }\end{array}$ & A21202 & \\
\hline
\end{tabular}

\begin{tabular}{|c|c|c|c|c|c|}
\hline \multicolumn{7}{|c|}{ Antibodies (Western Blotting) } \\
\hline Antigen & Figure & Diluting factor & Company & Cat. No. & $\begin{array}{c}\text { Batch } \\
\text { No. }\end{array}$ \\
\hline GapDH & 5 & $1: 500$ & Santa Cruz & SC-32233 & H2114 \\
\hline Lamin A/C & 5 & $1: 400$ & Cell Signalling & 4777 & \\
\hline $\begin{array}{c}\text { Anti-Rabbit } \\
\text { HRP }\end{array}$ & 5 & $1: 500$ & Cell Signalling & $7074 \mathrm{P} 2$ & \\
\hline $\begin{array}{c}\text { Anti-Mouse } \\
\text { HRP }\end{array}$ & 5 & $1: 500$ & Cell Signalling & $7076 \mathrm{P} 2$ & \\
\hline
\end{tabular}

\begin{tabular}{|c|c|c|c|}
\hline \multicolumn{3}{|c|}{ Primers } \\
\hline $\begin{array}{c}\text { Gene } \\
\text { (mouse) }\end{array}$ & Forward primer ('5-'3) & Reverse primer ('5-'3) & $\begin{array}{c}\text { PCR } \\
\text { Product size }\end{array}$ \\
\hline
\end{tabular}




\begin{tabular}{c|lll|}
\cline { 2 - 4 } Hes1 & TGAGCCAGCTGAAAACACTG & AGCACACTTGGGTCTGTGC & 160 \\
DLl1 & GCACGGACCTCAAGTACTCC & ATGCTGCTCATCACATCCAG & 200 \\
Hey1 & CTTTTGGTGCATGGAACTGT & CAGTTCAGTGGAGGTCGTTT & 152 \\
DLL4 & GCGAGAAGAAAGTGGACAGG & ATTCTCCAGGTCATGGCAAG & 185 \\
Jag1 & ATCGTGCTGCCTTTCAGTTT & ATTGCAGCCAAAGCCATAGT & 234 \\
Acta2 & CAGATGTGGATCAGCAAACA & TGGCTAGGAATGATTTGGAA & 161 \\
BGLAP & CAGCGAGGTAGTGAAGAG & GGGAAGAGGAAAGAAGGG & 249 \\
Runx2 & CTCTGACCGCCTCAGTGATT & GGCTCAGGTAGGAGGGGTAA & 200 \\
Periostin & CAAAACTGAAGGACCCACAC & TATTTCCACAGGCACTCCAT & 154 \\
Sparc & GTGCAGAGGAAACCGAAGAG & AAGTGGCAGGAAGAGTCGAA & 200 \\
GapDH & ATCACTGCCACCCAGAAGAC & CAGTGAGCTTCCCGTTCAG & 148 \\
36 B 4 & GCAATGTTGCCAGTGTCTGT & GCCTTGACCTTTTCAGCAAG & 142 \\
SPP1 & TTGCAGTGATTTGCTTTTGC & GTCATGGCTTTCGTTGGACT & 200 \\
Dlk1 & GGCTTCATCGACAAGACCTG & CAGGTCTCGCACTTGTTGAG & 185 \\
\hline
\end{tabular}

\begin{tabular}{|c|c|c|c|}
\hline \multicolumn{3}{|c|}{ Recombinant Proteins } \\
\hline Protein & Company & Cat. No. & Lot \\
\hline $\begin{array}{c}\text { Human } \\
\text { Jagged 1 }\end{array}$ & R\&D & $1277-J G-050$ & RZL1713041 \\
\hline
\end{tabular}

